\title{
The influence of gender on the entrepreneurial intentions of journalism students
}

\author{
Francisco-Javier Caro-González (D), Helios Romero-Benabent (iD, Isadora Sánchez-Torné(D) \\ Universidad de Sevilla (Spain) \\ fjcaro@us.es,romerohelios@gmail.com, isadorasanchestorne@gmail.com
}

Received October, 2016

Accepted January, 2017

Versión en español

\section{Abstract}

Purpose: The purpose of this paper is to understand the gender differences in the formation of entrepreneurial intentions among future communications professionals. Building on the Theory of Planned Behavior (TPB), it analyzes the relationships between the variables of personal attitude towards entrepreneurship (AE), perceived behavioral control (PBC) and the influence of the social environment of entrepreneurs on their entrepreneurial intention (EI).

Design/methodology: This empirical research is based on a non-random convenience sample consisting of 234 students enrolled in the final courses of the journalism degree program. The models have been tested according to the PLS (Partial Least Square) method.

Findings: The results indicate the existence of explanatory models of different entrepreneurial intentions for men and women. In this regard, the significant relationship between social norms and social assessment in the entrepreneurial intention of women is important.

Research limitations/implications: This study analyzes communications students, and although the theory of planned behavior is quite strong, the results cannot be generalized to sector professionals. 
Practical implications: Research like this helps identify the background on which to act and to be developed in the training programs of future communicators. From the point of view of research, this study reveals the usefulness of TBP.

Social implications: Improved employability of professionals in the communications sector, with attention to the differences between men and women when considering entrepreneurship as a career option.

Originality/value: This is the first study of its kind conducted in the context of communications and with university students, specifically, those pursuing a degree in communications, who are faced with an economic crisis and a changing environment, in which entrepreneurship is critical to their professional development.

Keywords: Journalism, Entrepreneurial intention, Gender, Students, Theory of Planned Behavior, Structural Equation Modeling, PLS

Jel Codes: I23, L82, J26

\section{Introduction}

The emergence of digital technology in all spheres of the communications sector (production, distribution and consumption) is generating drastic changes in the mass media (Jarvis, 2015). This has led to many communicators being compelled to engage in the informative activity on their own account, either as freelancers or by creating their own media.

In Spain, the impact of these transformations has been particularly harsh. According to the Annual Report of the Journalism Profession edited by the Madrid Press Association (APM) (Palacios, 2015), between 2008 and 2015, a total of 12,200 jobs have been destroyed and 375 media companies have closed their doors. Similarly, labor conditions have worsened: the average base salary for communications professionals covered by a collective bargaining agreement has been reduced by $17 \%$ since 2010 , and $25 \%$ of freelance journalists have experienced a $70 \%$ decline in their income.

As a result, journalists believe that the two main problems faced by the profession are "increased unemployment and job instability" and "the poor compensation for journalistic work." If the labor 
conditions of female journalists are analyzed, it can be seen that $62.5 \%$ of those hired earn less than $€ 1000$, as compared to $46.4 \%$ of men. A glass ceiling also exists, which serves as a barrier to executive positions; only $15.9 \%$ of these positions are held by women, a percentage which has held steady over time since before the crisis (Caro-González, García-Gordillo, Rodríguez-Rad \& Jiménez-Marín, 2007).

In this context, one third of the journalists indicate that they have been forced to do freelance work (Palacio, 2015). It would appear that most of these freelancers are women, as the precarious labor conditions are an incentive for self-employment (Dyer, 1994). Creating their own business would allow them to break through the glass ceiling, accessing more equal pay and executive positions in the organizations. However, the aforementioned report from the Madrid Press Association (Palacio, 2015) indicates that only $40.3 \%$ of freelance workers are women. This figure does not seem to make sense if we take into consideration that between 2011 and 2014 a total of 15,807 journalists earned their degrees in Spain, of whom more than 65\% are women. This information is in line with the data from the GEM (Global Entrepreneurship Monitor) report for Spain (Peña et al., 2016, pp. 126), where $58.5 \%$ of the new and fledgling entrepreneurs are men.

In order to understand the reasons for the lower rates of entrepreneurship in women, we must ask ourselves whether there are any differences in the variables explaining it. Discovering these differences can help to design programs of incentives and training in entrepreneurship that improve the ratio of the participation of women in entrepreneurial activities (Díaz-García \& Jiménez-Moreno, 2010).

Researchers pay attention to entrepreneurial intention because it is a predictor of behavior. Martínez, Mira and Gómez (2010) and Ventura and Quero (2013) consider the understanding of entrepreneurial intention to be very relevant in order to reveal the reasons for the lower rates of entrepreneurship in the female population. Entrepreneurs are characterized by their ability to detect opportunities in their surroundings and to innovate in order to take advantage of them. This process is intentional, and thus the development of this intention can be considered the first step towards the creation of a new company (Crant, 1996; Krueger \& Carsrud, 1993; Lee \& Wong, 2004). An increase in entrepreneurial intention would subsequently lead to an increase in entrepreneurship (Ajzen, 2005).

The consideration of gender in this field reveals contradictory results. Part of the researchers do not consider it to be very important when explaining the intention to found a business (Armitage \& Conner, 2001; Pruett, Shinnar, Toney, Llopis \& Fox, 2009). They believe that the gender of the person has no influence on their intention to engage in entrepreneurship, and is used as a control variable. 
However, there are other researchers who argue that the influence of gender is not noticeable because the methodological and theoretical approaches are inappropriate and, therefore, the influence of gender on entrepreneurial intention has not been studied in depth and requires further study before any final conclusions can be reached (Shay \& Terjesen, 2005; Shook \& Bratianu, 2010; Kobeissi, 2010). The indirect effect of gender on entrepreneurial intention is explained in few studies (Kickul, Krueger \& Maxfield, 2005; Wilson, Kickul \& Marlino, 2007; Goyanes, 2015).

With this study, we wish to contribute new empirical evidence on the topic, analyzing the entrepreneurial intention from the perspective of gender in the case of journalism students. The Theory of Planned Behavior (TPB) is used to better understand the extent to which gender influences entrepreneurial intention (EI) and its antecedents. This theory is the model most commonly used to study entrepreneurial intentions (Arias, Restrepo \& Restrepo, 2016), and it has provided generally accepted results, explaining an amount of variance in EI ranging from 0.27 to 0.65 (Armitage \& Conner, 2001; Ajzen, 2005).

The TPB model was tested on a population of 234 students in the final years of the journalism degree program. The results are obtained from structural equation models analyzed using the PLS program.

The article is structured as follows: first, the Planned Behavior Theory model is described that is used as the basis for the study; next, the methodology used is explained, namely the PLS (Partial Least Square) method; finally, the results are reported and contrasted with the previous literature. This work ends with a discussion of the most important theoretical and methodological contributions and their implications to the training of future journalism professionals in entrepreneurship.

\section{Theoretical framework}

To find out the impact of gender on the intention to engage in entrepreneurial activities by future professional journalists, the Theory of Planned Behavior (TPB) is used (Ajzen, 1991). The basic premise of this theory is that there is a strong link between the intention to act and real behavior. Armitage and Conner (2001), in a meta-analysis of 185 research studies using the TPB model, demonstrated that this theory could explain $27 \%$ of the variance in behavior and $39 \%$ of the entrepreneurial intention. 
The literature on entrepreneurial intention (EI) clearly shows the usefulness of TPB in demonstrating that there is a link between the antecedents of the EI, the intention itself and behavior (Krueger, Reilly \& Carsrud, 2000; Guerrero, Rialp \& Urbano, 2008).

The TPB model can be seen in Figure 1. The dependent variable is the entrepreneurial intention (EI) and the independent variables are the attitude towards entrepreneurship (AE), the perceived behavioral control (PBC), social norms (SN) and social evaluation (SE).

Entrepreneurial intention (EI) constitutes the key to understanding the entrepreneurial process. "A person develops the intention to perform a certain behavior; this intention remains as a predisposition until, when the appropriate time and opportunity come, the intention is transformed into an action" (Ajzen, 2005). In our case, EI represents a construct that connects the process of detecting an opportunity with actually carrying it out (Dimov, 2007; Carsrud \& Brännback, 2011). This variable is one of the most viable precursors of entrepreneurial behavior, which will lead to the creation of new businesses (Prodan \& Drnovsek, 2010).

Perceived behavioral control (PBC) is another latent variable that plays an important role in predicting EI and entrepreneurial behavior in communications. This construct reflects the perception of the ability an individual has to create and manage a new business (Jaén, 2010). Researchers vary in their use of the term and often use PBC interchangeably with self-efficacy, or add small nuances that differentiate between these terms (Krueger et al, 2000). Authors such as Armitage and Conner (2001) and Pruett et al. (2009) found a significant link between PBC and EI. However, in the multicultural work of Engle et al. (2010), it was observed that the relationship between PBC and EI was only significant in seven of the twelve countries studied. It therefore continues to be interesting to study this relationship in different contexts, such as the unique case of journalism students in Spain.

In any case, the $\mathrm{PBC}$ construct is among the strongest predictors of EI, along with $\mathrm{AE}$, and it is repeatedly used to explain EI (Ajzen, 2005).

The attitude towards entrepreneurship (AE) constitutes the third construct of the model. It is a personal factor that indicates the individual's desire to create value by exerting entrepreneurial behavior (Fini, Grimaldi, Marzocchi \& Sobrero, 2012). The positive, direct correlation with EI has been established in different studies (Engle et al., 2010; Liñán, Rodríguez-Cohard \& Rueda-Cantuche, 2011).

Other constructs that help understand the antecedents of entrepreneurial intention are social norms (SN) and social evaluation (SE). It is a matter of finding out the extent to which an individual's 
environment influences his or her behavior when engaging in entrepreneurial activities (White, Smith, Terry, Greenslade \& McKimmie, 2009). If the social environment values the business activity and it is believed that the individual has the necessary knowledge and skills, they will be more motivated and feel capable of starting a business (Gallurt Plá, 2010).

In this case, the influence on the future entrepreneur depends on his or her parents, friends and other people who can somehow promote or disapprove of the idea of entrepreneurship. Some studies confirm that the social norms directly affect EI (Pruett et al., 2009; Engle et al., 2010). However, Shook and Bratianu (2010) found a negative relationship between context norms and EI. Krueger et al. (2000) and Armitage and Conner (2001) also reported a weak relationship between the two variables. In this sense, it is interesting to refer to other studies that contribute to clarifying this debate.

Finally, Ajzen (2005) and Guerrero, Lavin and Álvarez (2009) found an indirect effect of the social norms and assessments on EI with the mediation of $\mathrm{AE}$ and PBC. Social pressure tends to promote a favorable attitude towards entrepreneurship and can also increase the PBC, thus impacting the EI. Zahra, Gedajlovic, Neubaum and Shulman (2009) consider the impact of culture to be decisive, as defined through social evaluation and social norms in business behavior.

As observed, in spite of the support received in the literature, the results of the works that use TPB do not always coincide. Along these lines, while Gird and Bagraim (2008) indicated a significant relationship among the three antecedents of EI and the intention to start a business, Liñan and Chen (2009) demonstrated that there is no link between EI and social norms, corroborating the previous findings of Krueger et al. (2000). Engle et al. (2010), in their study with samples from twelve countries, found that in half of them, the predictors of EI were social norms and the desire to engage in entrepreneurship, while in the other half, they were social norms and perceived behavioral control.

The repercussion of this latter work points in the direction of carrying out more specific studies using TPB, instead of trying to identify universal models. Research studies are very homogeneous and have not taken into account contextual factors (Elfving, 2008; Kickul, Gundry, Barbosa \& Whitcanack, 2009). Furthermore, as indicated by Alonso-García (2012), a large part of the studies are based on data collected in the United States and there are, with a few exceptions, not many international works that compare different social and cultural environments (De Pillis \& Reardon, 2007; Delmar \& Davidsson, 2000; Liñán \& Chen, 2009). With this study, the intent is to contribute evidence on the TPB model applied to entrepreneurship in the specific sector of communications. 


\section{Objectives and hypothesis}

The aim of this study is to analyze the entrepreneurial intention of journalism students from the perspective of gender and within the framework of Planned Behavior Theory. This will enable us to test the validity of the model in the case of journalism students and identify significant differences in the model, according the gender of the person surveyed.

As described in the theoretical framework, the TBP model measures entrepreneurial intention (EI) based on the variables perceived behavioral control (PBC) and attitude towards entrepreneurship (AE). This proposal is enriched by two antecedents: on the one hand, social norms ( $\mathrm{SN})$, and on the other, the social evaluation of entrepreneurship (SE).

The TBP model that will be analyzed is shown in Figure 1.

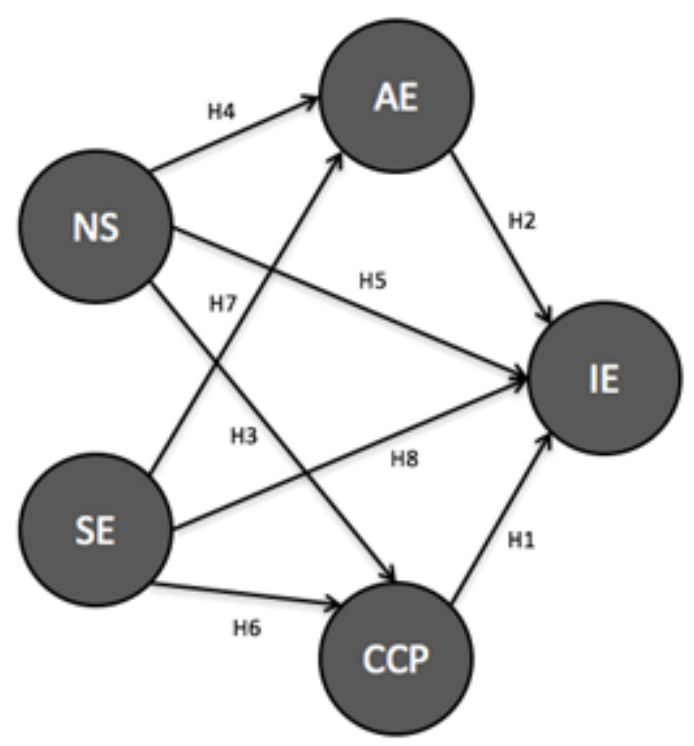

Figure 1. Proposed model and hypotheses 
According to the previous theoretical analysis, the following hypotheses are proposed:

H1: PBC is positively related to EI.

H2: $A E$ is positively related to EI.

H3: SN is positively related to $P B C$.

H4: $S N$ is positively related to $A E$.

H5: SN is positively related to EI.

H6: SE is positively related to $P B C$.

H7: SE is positively related to $A E$.

H8: SE is positively related to EI.

Similarly, if the gender of the students is taken into account, differences can be expected between the models explaining entrepreneurial intention.

\section{Methodology, analysis and results}

This empirical research is based on a non-random convenience sample. In particular, the data were collected through a questionnaire linked to the Facebook page of the business creation courses in the College of Communications at the University of Seville. The universe of students is a very commonly used context in this type of research (Krueger et al., 2000; Lüthje \& Franke, 2003; Fayolle \& Gailly, 2004; Souitaris, Zerbinati \& Al-Laham, 2007; Ventura \& Quero, 2013). The literature has evidenced several reasons that back the use of this population to analyze entrepreneurial intentions (Arias et al., 2016). Among them is the fact that university students will soon have to make a decision about their professional future, and therefore statements about their intentions are premeditated (Liñán \& Santos, 2007). Consequently, they constitute a potentially entrepreneurial group (Sánchez, Lanero \& Yurrebaso, 2005) that is considered to be representative of the population in order to analyze human behavior (Harrison \& List, 2004).

The questionnaire was administered at the start of the courses to all students registered during the academic years 2013-14, 2014-15 and 2015-16. The final number of students surveyed, once the invalid 
surveys were eliminated, was 234 . The gender composition of this sample is in accordance with that of the universe explored (69.27\% female students and 30.73\% male students).

The questions on the questionnaire were obtained from scales previously tested in different studies. In particular, the questionnaire used by Sahinidis, Giovanis and Sdrolias (2012) was adapted, which was constructed based on the instruments created by Liñán and Chen (2009) and Guerrero et al. (2009).

\subsection{Assessment of the research model}

To test the research model, a Partial Least Squares (PLS) approach was used for structural equation models (SEM) (Chin, 1998; Tenenhaus, Vinzi, Chatelin \& Yves-Marie, 2005).

The reasons for using PLS instead of other types of statistics modeling programs with structural equations are (Diamantopoulos \& Winklhofer, 2001; Rigdon, 2016):

- the exploratory nature of this work;

- PLS does not require large samples, as opposed to other statistics programs (AMOS, EQS, etc.), to obtain results;

- PLS is a non-parametric technique, and therefore it is not necessary to ensure a normal data distribution.

The proposed model was assessed for each group, i.e., women (G1) and men (G2).

A structural equation model is described by two models:

- a model of measurement between the manifest variables (MVs) and their own latent variables (LVs) and

- a structural model of the relationships between the endogenous and exogenous variables.

Figures 2 and 3 show the model in G1 and G2, once the PLS algorithm has been applied (Ringle, Wende \& Will, 2005) and the indicators have been removed that have a lambda coefficient of less than 0.7 in either model (pa1, sn3, sv3, pbc1, pbc4, pbc5). This ensures that the shared variance between the construct and its indicators is greater than the variance due to error (Carmines \& Zeller, 1979).

Therefore, the resulting model that is valid for both G1 and G2 would be: 


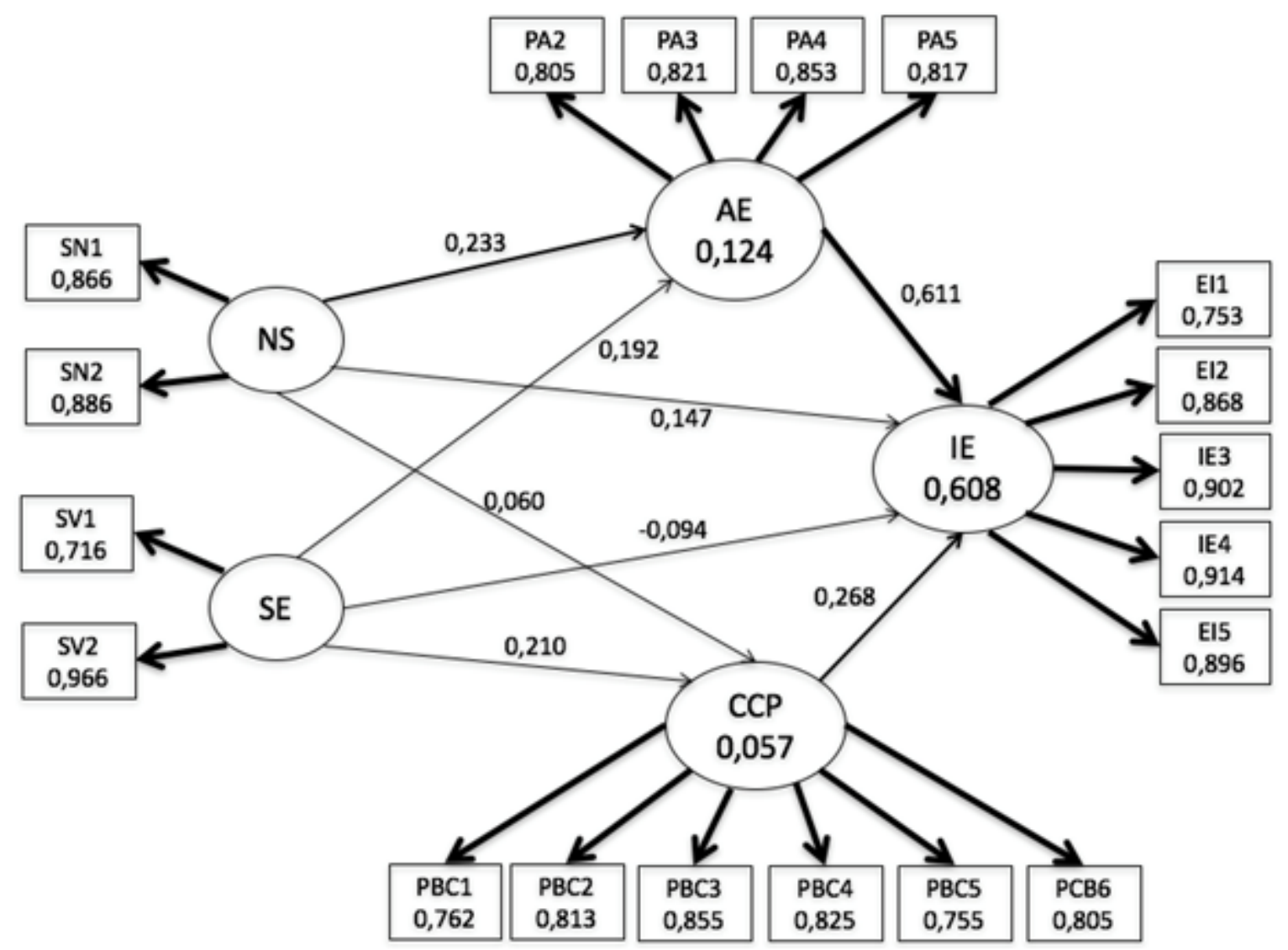

Figure 2. R-squared model and estimated path of the PLS analysis for G1 (women) 


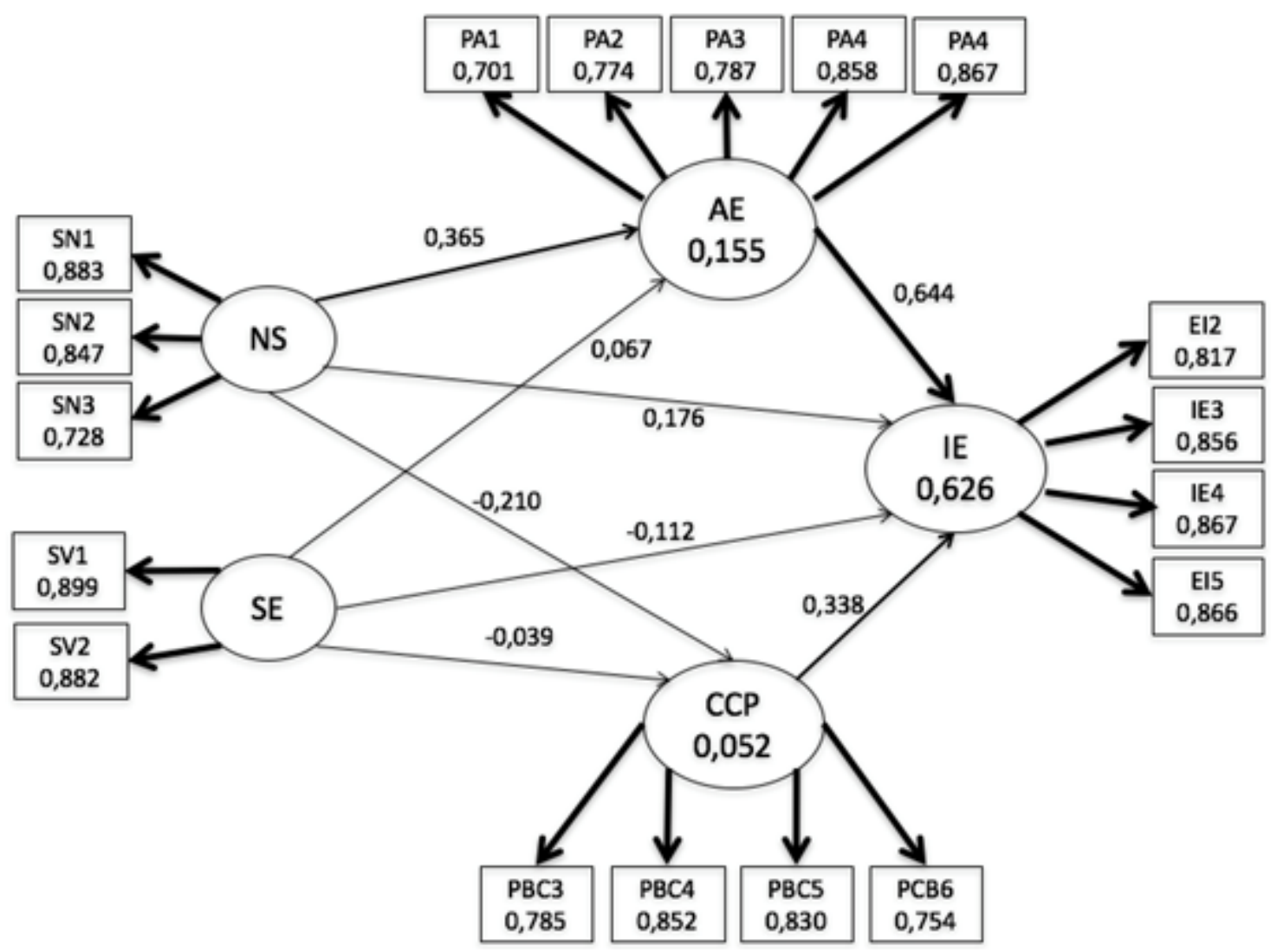

Figure 3. R-squared model and estimated path of the PLS analysis for G2 (men)

\subsection{Measurement model analysis}

The reliability and validity of the measurement models were determined prior to the analysis of the structural model. The individual reliability of each indicator was evaluated by examining the loads $(\lambda)$ or simple correlations with their respective latent variables $(\mathrm{LV})$. The indicators were accepted when $\lambda \geq$ 0.707. Furthermore, the indicators needed to be more strongly correlated with their own construct than with any other (Fornell \& Larcker, 1981).

Table 1 shows the results of the cross loading procedure for Group 1 and Group 2. 


\begin{tabular}{|c|c|c|c|c|c|c|c|c|c|c|}
\hline & \multicolumn{5}{|c|}{ G1 Women } & \multicolumn{5}{|c|}{ G2 Men } \\
\hline & AE & CCP & SE & IE & NS & AE & CCP & SE & IE & NS \\
\hline ei1 & 0.420 & 0.498 & 0.163 & 0.753 & 0.297 & - & - & - & - & - \\
\hline ei2 & 0.654 & 0.365 & 0.180 & 0.868 & 0.375 & 0.667 & 0.32 & 0.069 & 0.817 & 0.173 \\
\hline ei3 & 0.722 & 0.425 & 0.160 & 0.902 & 0.299 & 0.639 & 0.227 & 0.012 & 0.856 & 0.4 \\
\hline ei4 & 0.675 & 0.414 & 0.195 & 0.914 & 0.248 & 0.507 & 0.302 & 0.016 & 0.867 & 0.277 \\
\hline ei5 & 0.654 & 0.467 & 0.139 & 0.896 & 0.243 & 0.589 & 0.336 & 0.024 & 0.866 & 0.209 \\
\hline pa1 & - & - & - & - & - & 0.701 & 0.176 & 0.11 & 0.52 & 0.15 \\
\hline pa2 & 0.805 & 0.184 & 0.248 & 0.562 & 0.256 & 0.774 & -0.095 & 0.268 & 0.514 & 0.414 \\
\hline pa3 & 0.821 & 0.222 & 0.271 & 0.599 & 0.256 & 0.787 & -0.107 & 0.072 & 0.532 & 0.437 \\
\hline pa4 & 0.853 & 0.358 & 0.24 & 0.585 & 0.241 & 0.858 & 0.049 & 0.186 & 0.583 & 0.283 \\
\hline pa5 & 0.817 & 0.454 & 0.161 & 0.653 & 0.248 & 0.867 & 0.221 & 0.137 & 0.683 & 0.248 \\
\hline pbc1 & 0.405 & 0.762 & 0.191 & 0.389 & 0.178 & - & - & - & - & - \\
\hline pbc2 & 0.259 & 0.813 & 0.173 & 0.410 & 0.155 & - & - & - & - & - \\
\hline pbc3 & 0.340 & 0.855 & 0.215 & 0.472 & 0.144 & 0.039 & 0.785 & -0.079 & 0.248 & -0.152 \\
\hline pbc4 & 0.235 & 0.825 & 0.248 & 0.298 & 0.065 & 0.101 & 0.852 & -0.053 & 0.257 & -0.323 \\
\hline pbc5 & 0.248 & 0.755 & 0.195 & 0.274 & 0.01 & -0.057 & 0.83 & -0.12 & 0.23 & -0.211 \\
\hline pbc6 & 0.285 & 0.805 & 0.114 & 0.473 & 0.074 & 0.088 & 0.754 & -0.117 & 0.381 & -0.016 \\
\hline sn1 & 0.222 & 0.167 & 0.238 & 0.290 & 0.866 & 0.356 & -0.226 & 0.33 & 0.27 & 0.883 \\
\hline $\operatorname{sn} 2$ & 0.307 & 0.078 & 0.404 & 0.295 & 0.886 & 0.246 & -0.138 & 0.28 & 0.25 & 0.847 \\
\hline $\operatorname{sn} 3$ & - & - & - & - & - & 0.338 & -0.175 & 0.242 & 0.244 & 0.728 \\
\hline sv1 & 0.122 & 0.094 & 0.716 & 0.060 & 0.277 & 0.192 & -0.069 & 0.899 & 0.074 & 0.301 \\
\hline sv2 & 0.297 & 0.251 & 0.966 & 0.214 & 0.353 & 0.153 & -0.134 & 0.882 & -0.012 & 0.32 \\
\hline
\end{tabular}

Table 1. Results of the cross loading procedure for Groups 1 and 2

The reliability of the LV indicates the precision with which the observed variables measure it. The combined reliability was used as the reliability index for the LVs (LVs were accepted when $\alpha>0.7)$. The convergent validity of the LVs was evaluated by examining the average variance extracted (AVE); see Fornell and Larcker (1981) (AVEs> 0.5 were accepted). Table 2 shows the combined reliability, the AVE and Cronbach's alpha for each LV. The latter is adequate in all constructs in the case of Group 2. In Group 1, the constructs SE and SN are very close to 0.7 , which is considered an acceptable value (George \& Mallery, 2003, pp. 231).

\begin{tabular}{|l|r|r|r|r|r|r|}
\cline { 2 - 7 } \multicolumn{1}{c|}{} & \multicolumn{3}{c|}{ G1 Women } & \multicolumn{3}{c|}{ G2 Men } \\
\cline { 2 - 7 } \multicolumn{1}{c|}{} & $\begin{array}{c}\text { Combined } \\
\text { reliability }\end{array}$ & AVE & $\begin{array}{c}\text { Cronbach's } \\
\text { alpha }\end{array}$ & $\begin{array}{c}\text { Combined } \\
\text { reliability }\end{array}$ & AVE & $\begin{array}{c}\text { Cronbach's } \\
\text { alpha }\end{array}$ \\
\hline AE & 0.894 & 0.679 & 0.842 & 0.898 & 0.640 & 0.858 \\
\hline PBC & 0.916 & 0.645 & 0.891 & 0.881 & 0.650 & 0.820 \\
\hline SE & 0.836 & 0.723 & 0.677 & 0.884 & 0.793 & 0.739 \\
\hline EI & 0.939 & 0.755 & 0.918 & 0.913 & 0.725 & 0.874 \\
\hline SN & 0.869 & 0.768 & 0.698 & 0.861 & 0.676 & 0.757 \\
\hline
\end{tabular}

Table 2. Combined reliability and AVE 
The discriminant validity of the latent variables was tested, analyzing whether the square root of the AVE for each LV was greater than the correlations with the rest of the LVs (see Table 3).

\begin{tabular}{|l|l|l|r|r|r|r|r|r|r|r|}
\cline { 2 - 12 } \multicolumn{1}{c|}{} & \multicolumn{4}{c|}{ G1 Women } & \multicolumn{6}{c|}{ G2 Men } \\
\cline { 2 - 12 } \multicolumn{1}{c|}{} & AE & CCP & SE & IE & NS & AE & CCP & SE & IE & NS \\
\hline AE & 0.824 & & & & & 0.8 & & & & \\
\hline $\mathbf{C C P}$ & 0.373 & 0.803 & & & & 0.058 & 0.806 & & & \\
\hline SE & 0.278 & 0.232 & 0.85 & & & 0.194 & -0.113 & 0.89 & & \\
\hline IE & 0.729 & 0.493 & 0.192 & 0.869 & & 0.711 & 0.348 & 0.036 & 0.852 & \\
\hline NS & 0.304 & 0.138 & 0.37 & 0.334 & 0.876 & 0.389 & -0.224 & 0.348 & 0.312 & 0.822 \\
\hline
\end{tabular}

Table 3. LV correlations for Groups 1 and 2 (elements in diagonal are the square roots of the AVE)

In addition, the heterotrait-monotrait (HTMT) ratio was calculated, which detects the lack of discriminant validity (Table 4) better than the cross loading examination and the Fornell-Larcker criterion (Henseler, Ringle \& Sarstedt, 2015). The HTMT ratio must be below 0.85 (Kline, 2011).

\begin{tabular}{|l|r|r|r|r|r|r|r|r|r|r|}
\cline { 2 - 12 } \multicolumn{1}{c|}{} & \multicolumn{4}{c|}{ G1 Women } & \multicolumn{1}{c|}{ Gen } & \multicolumn{1}{c|}{ G2 } \\
\cline { 2 - 12 } \multicolumn{1}{c|}{} & \multicolumn{1}{c|}{ AE } & CCP & SE & IE & NS & AE & CCP & SE & IE & NS \\
\hline AE & & & & & & & & & & \\
\hline $\mathbf{C C P}$ & 0.42 & & & & & 0.194 & & & & \\
\hline SE & 0.32 & 0.276 & & & & 0.243 & 0.163 & & & \\
\hline IE & 0.818 & 0.538 & 0.2 & & & 0.813 & 0.41 & 0.093 & & \\
\hline NS & 0.394 & 0.181 & 0.524 & 0.421 & & 0.468 & 0.27 & 0.464 & 0.381 & \\
\hline
\end{tabular}

Table 4. Heterotrait-monotrait (HTMT) ratio for Groups 1 and 2

The previous works on which this study is based (Sahinidis et al., 2012; Liñán \& Chen, 2009; Guerrero et al., 2009) obtained similar results from the validation of the measurement scale of the model. Specifically, they achieved a Cronbach's alpha higher than 0.7 and the measurement variables were strongly correlated with the constructs to which they belonged. 


\subsection{Structural Model Analysis}

After checking the validity and reliability of the measurement model, the relationships between the constructs were tested. The hypotheses were tested by examining the path coefficients $(\beta)$ and their levels of significance (they were accepted when $\beta>=0.2$ ). Bootstrapping was carried out with 500 subsamples in order to check the statistical significance of each of the path coefficients. The explained variance $\left(R^{2}\right)$ in the endogenous LVs and the regression significance coefficient (F-test) serve as indicators of the explanatory capacity of the model.

\begin{tabular}{|c|c|c|c|c|c|c|c|c|c|c|}
\hline & \multicolumn{5}{|c|}{ G1 Women } & \multicolumn{5}{|c|}{ G2 Men } \\
\hline & $\begin{array}{l}\text { Original } \\
\text { Sample } \\
\text { (O) }\end{array}$ & $\begin{array}{c}\text { Sample } \\
\text { Mean } \\
\text { (M) }\end{array}$ & $\begin{array}{l}\text { Standard } \\
\text { Deviation } \\
\text { (STDEV) }\end{array}$ & $\begin{array}{c}\text { T Statistics } \\
(|\mathrm{O} / \mathrm{STDEV}|)\end{array}$ & $\begin{array}{c}\mathbf{P} \\
\text { Values }\end{array}$ & $\begin{array}{l}\text { Original } \\
\text { Sample } \\
\text { (O) }\end{array}$ & \begin{tabular}{|c|} 
Sample \\
Mean \\
(M)
\end{tabular} & $\begin{array}{l}\text { Standard } \\
\text { Deviation } \\
\text { (STDEV) }\end{array}$ & $\begin{array}{c}\text { T Statistics } \\
(\mid \mathrm{O} / \text { STDEV } \mid)\end{array}$ & $\begin{array}{c}\mathbf{P} \\
\text { Values }\end{array}$ \\
\hline AE -> IE & 0.611 & 0.613 & 0.05 & 12.325 & $0.000^{*}$ & 0.644 & 0.642 & 0.089 & 7.241 & $0.000^{*}$ \\
\hline CCP -> IE & 0.268 & 0.272 & 0.058 & 4.623 & $0.000 *$ & 0.337 & 0.34 & 0.09 & 3.732 & $0.000^{*}$ \\
\hline SE -> AE & 0.192 & 0.196 & 0.081 & 2.37 & $0.018^{*}$ & 0.067 & 0.087 & 0.133 & 0.505 & 0.614 \\
\hline SE ->CCP & 0.21 & 0.22 & 0.086 & 2.436 & $0.015^{*}$ & -0.039 & -0.03 & 0.165 & 0.238 & 0.812 \\
\hline SE -> IE & -0.094 & -0.096 & 0.055 & 1.724 & 0.085 & -0.112 & -0.112 & 0.077 & 1.456 & 0.146 \\
\hline NS $->$ AE & 0.233 & 0.244 & 0.094 & 2.47 & $0.014 *$ & 0.365 & 0.365 & 0.146 & 2.495 & $0.013^{*}$ \\
\hline NS ->CCP & 0.060 & 0.063 & 0.098 & 0.608 & 0.543 & -0.21 & -0.21 & 0.191 & 1.1 & 0.272 \\
\hline NS -> IE & 0.147 & 0.142 & 0.063 & 2.319 & $0.021 *$ & 0.176 & 0.176 & 0.101 & 1.733 & 0.084 \\
\hline
\end{tabular}

Table 5. Results of the PLS analyses for G1 and G2

In can be seen in Table 5 that the following relationships are significant:

AE -> EI in both cases.

PBC -> EI in both cases.

SE -> AE, only in G1.

SE -> PBC, only in G1.

$\mathrm{SN}->\mathrm{AE}$ in both cases.

SN -> EI, only in G1. 
The explained variance for each variable in both groups is shown in Table 6:

\begin{tabular}{|l|r|r|}
\cline { 2 - 3 } \multicolumn{1}{c|}{} & \multicolumn{2}{c|}{ R Square } \\
\cline { 2 - 3 } \multicolumn{1}{c|}{} & G1 Women & G2 Men \\
\hline AE & 0.124 & 0.155 \\
\hline CCP & 0.057 & 0.052 \\
\hline IE & 0.608 & 0.626 \\
\hline
\end{tabular}

Table 6. Explained variance $\left(\mathrm{R}^{2}\right)$ in endogenous $L V s$

With these results, the hypotheses $\mathrm{H} 1, \mathrm{H} 2, \mathrm{H} 4, \mathrm{H} 5, \mathrm{H} 6$ and $\mathrm{H} 7$ are supported for Group 1 and the hypotheses H1, H2 and H4 are confirmed for Group 2.

As a result, we can establish that the TBP model would be as follows (see Figure 4):

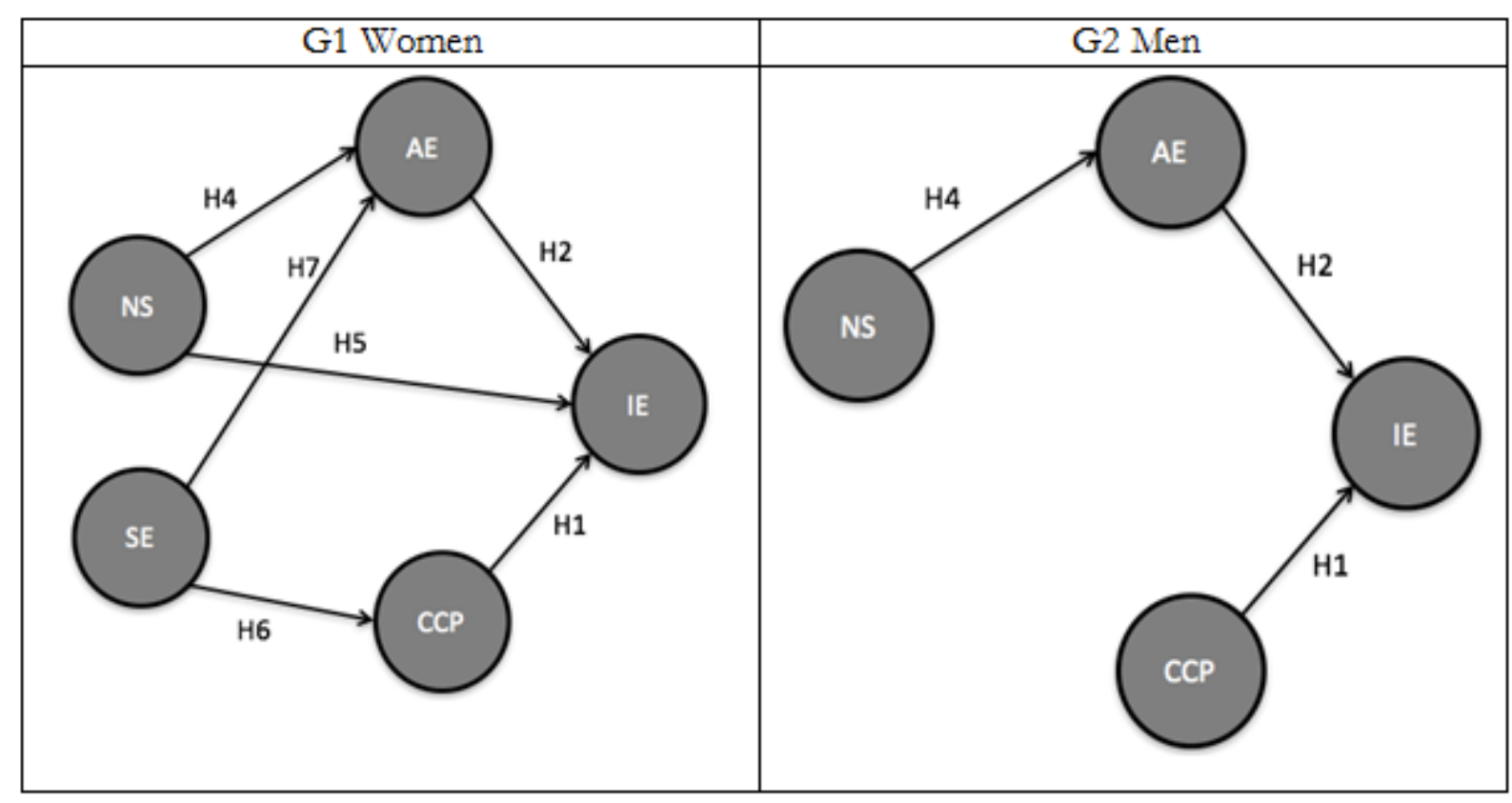

Figure 4. Final TPB model 


\section{Conclusions}

The Planned Behavior Theory model is a useful tool to explain the entrepreneurial intention of journalism students who lack business training. Most existing studies on this topic have analyzed these constructs in students registered in degree programs related to the business world (Sagie \& Elizur, 1999; DeMartino \& Barbato, 2002; Krueger et al., 2000; Gatewood, Shaver, Powers \& Gartner, 2002; Lüthje \& Franke, 2003; Liñán, Rodríguez-Cohard \& Rueda-Cantuche, 2005; Wilson et al., 2007; Zhao, Seibert \& Hills, 2005; Sahinidis et al., 2012; Wurthmann, 2014). Moreover in this case, these are students who are faced with a context of economic crisis and change, where entrepreneurship is essential for their career development. The robustness of the TBP model has been verified in order to explain the entrepreneurial intention of the future communications professionals, both in the case of men and women, with an explained variance of 0.626 and 0.608 , respectively.

The measurement model and structural model are valid. However, differences are evident in terms of the significant relationships between constructs, revealing that in the case of women, the exogenous variables $\mathrm{SN}$ and $\mathrm{SE}$ have both a direct $(\mathrm{SN})$ and indirect (SN and $\mathrm{SE}$ ) impact on the entrepreneurial intention, which is something that does not occur in the case of men, where the entrepreneurial intention is only indirectly impacted by SN. The literature review shows the opposite results; there are studies indicating that no direct relationship can be established between the subjective norms and the entrepreneurial intention (Krueger et al., 2000), while others demonstrate that said relationship does exist, and it is positive (Kolvereid \& Isaksen, 2006). It may be that the response to this controversy can be found in the gender of the population surveyed. Different studies indicate that there is an important relationship between gender and EI (Farrington, Venter \& Louw, 2012; Gird \& Bagraim, 2008; Engle et al., 2010; Sahinidis et al., 2012; Goyanes, 2015). More specifically, some of the studies that found that environmental factors barely had any influence on men, but they did affect women (Leroy, Maes, Sels, Debrulle \& Meuleman, 2009) are reinforced. In this regard, González-Serrano, Valantine, Campos, Berenguer, Moreno and Hervás (2016) observed that female physical activity and sports sciences students assess the social norm with a higher score than men. In the case of male journalism students, the relationships with one of the environmental variables were not significant.

The perception that women have, as future journalism professionals, regarding the assessment of the entrepreneurial activity by their closest environment directly and indirectly affects the intention to create a new business. The indirect impact of this perception is through the AE. In other words, women perceive that it is more attractive to create their own company if they believe that their immediate environment looks favorably upon entrepreneurial activity. This may be due to lower self- 
esteem that causes them to search for support beyond the perception of their own abilities. As a matter of fact, SN (assessment of entrepreneurship of the survey taker by people close to her) significantly influences, both directly and indirectly, the EI. We have found differences with regard to this point in the study by Sahinidis et al. (2012), which indicated that the environmental variables were related to both $\mathrm{AE}$ and PBC. It would be interesting to continue to investigate whether this difference is related to the professional orientation of the students studied or due to sociocultural aspects.

It has been concluded that entrepreneurship in the communications sector continues to be a male activity, in a masculine profession (Djerf-Pierre, 2007), where men need less approval from their environment, given that it is assumed that they can and should engage in entrepreneurial activities; however, in the case of women, it is necessary to reinforce the attractiveness of entrepreneurship with the support of their immediate environment.

More studies along these lines are necessary in order to identify the skills and competences that influence the entrepreneurial behavior of women. It is likely that variables such as confidence and selfesteem with regard to entrepreneurship are limiting the entrepreneurial capacity of women who seek approval from their environment to develop entrepreneurial behaviors. Instructors must attempt to transmit the attractiveness of entrepreneurship to female entrepreneurs.

\section{Implications}

It would seem, as most studies have indicated, that the long-term solution to reduce the gender differences involves modifying the educational system (Sahinidis et al., 2012). Studies like this one help identify the antecedents on which to act and that must be developed in training programs for future communications professionals. From a methodological perspective, this study reveals the usefulness and validity of the tested model. At the same time, it is considered necessary to conduct qualitative studies that make it possible to incorporate new indicators measuring constructs, such as SN and SE, which currently have few. Along similar lines, it is necessary to delve more deeply into gender differences, studying the inclusion of variables such as the existence of reference values, the labor situation of mothers and institutional support. Finally, researchers are encouraged to conduct studies focused on more specific professional populations, which would contribute to understanding the phenomenon of entrepreneurial intention in other areas in which the training program does not include contents related to the business world. 
Following the proposals of BarNir, Watson and Hutchins (2011), it is necessary to introduce in the teaching-learning processes of journalists dynamics in which success stories of female entrepreneurs in communications are presented, demonstrating that getting started in a business venture does not need to be a professional career option open exclusively to men (Brito, Cruz \& Hernández, 2014).

\section{Limitations of the study}

This study has two limitations. On the one hand, there is the fact that the entrepreneurial intention is measured statically. It would be very enriching to be able to follow a target population of study and find out what entrepreneurship is like throughout the subjects' professional careers. In other words, this would represent taking the step from intention to action. Furthermore, the fact that this study considered journalism students means that while Planned Behavior Theory is relatively solid, it cannot be generalized to other professionals in the sector. The data must be interpreted as an experiment, something that explains the entrepreneurial behavior in a specific context. In any case, the research is relevant due to the contribution it makes to metatheoretical studies on the topic and its integration intothe conclusions of previous studies and the introduction of structural equations in studies on journalism.

\section{References}

Ajzen, I. (1991). The theory of planned behavior. Organizational behavior and buman decision processes, 50(2), 179-211. https://doi.org/10.1016/0749-5978(91)90020-T

Ajzen, I. (2005). Attitudes, personality, and behavior. Reino Unido: McGraw-Hill Education.

Alonso-Galicia, P.E. (2012). La configuración de la intención emprendedora entre académicos responsables de proyectos de investigación en España. Un enfoque de género. Tesis de doctorado. Granada, Departamento de Economía financiera y Contabilidad, Universidad de Granada.

Arias, A.V., Restrepo, I.M., \& Restrepo, A.M. (2016). Intención emprendedora en estudiantes universitarios: Un estudio bibliométrico. Intangible Capital, 12(4), 881-922. https://doi.org/10.3926/ic.730

Armitage, C.J., \& Conner, M. (2001). Efficacy of the theory of planned behaviour: A meta-analytic review. British journal of social psychology, 40(4), 471-499. https://doi.org/10.1348/014466601164939 
BarNir, A., Watson, W.E., \& Hutchins, H.M. (2011). Mediation and moderated mediation in the relationship among role models, self-efficacy, entrepreneurial career intention, and gender. Journal of Applied Social Psychology, 41(2), 270-297. https://doi.org/10.1111/j.1559-1816.2010.00713.x

Brito, M.D.P.M., Cruz, A.M.B., \& Hernández, A.I.L. (2014). Un paso más en la investigación de la intención emprendedora del estudiante universitario: GUESSS. Revista de Estudios Empresariales, Segunda Época(2), 63-80.

Carmines, E.G., \& Zeller, R.A. (1979). Reliability and validity assessment. N. 07-017, Sage University Paper Series on Quantitative Applications in the Social Sciences. Beverly Hills, CA: Sage. https://doi.org/10.4135/9781412985642

Caro-González, F.J., García-Gordillo, M.D.M., Rodríguez-Rad, C.J., \& Jimenez-Marín, G. (2007). Techo de cristal en las empresas periodísticas: Percepción de las habilidades y capacidades de la mujer en las tareas de dirección. Ámbitos, (16), 395-407.

Carsrud, A., \& Brännback, M. (2011). Entrepreneurial motivations: What do we still need to know?. Journal of Small Business Management, 49(1), 9-26. https://doi.org/10.1111/j.1540-627X.2010.00312.x

Chin, W.W. (1998). The partial least squares approach to structural equation modeling. Modern methods for business research, 295(2), 295-336.

Crant, J.M. (1996). The proactive personality scale as a predictor of entrepreneurial intentions. Journal of small business management, 34(3), 42.

De Pillis, E., \& Reardon, K.K. (2007). The influence of personality traits and persuasive messages on entrepreneurial intention: A cross-cultural comparison. Career Development International, 12(4), 382-396. https://doi.org/10.1108/13620430710756762

Delmar, F., \& Davidsson, P. (2000). Where do they come from? Prevalence and characteristics of nascent entrepreneurs. Entrepreneurship \& Regional Development, 12(1), 1-23. https://doi.org/10.1080/089856200283063

DeMartino, R., \& Barbato, R. (2015). An analysis of the motivational factors of intending entrepreneurs. Journal of Small Business Strategy, 13(2), 26-36.

Diamantopoulos, A., \& Winklhofer, H.M. (2001). Index construction with formative indicators: An alternative to scale development. Journal of Marketing Research, 38, 269-277. 
Díaz-García, M.C., \& Jiménez-Moreno, J. (2010). Entrepreneurial intention: The role of gender. International Entrepreneurship and Management Journal, 6(3), 261-283. https://doi.org/10.1007/s11365-0080103-2

Dimov, D. (2007). Beyond the single-person, single-insight attribution in understanding entrepreneurial opportunities. Entrepreneurship Theory and Practice, 31(5), 713-731. https://doi.org/10.1111/j.15406520.2007.00196.x

Djerf-Pierre, M. (2007). The Gender of Journalism. The Structure and Logic of the Field in the Twentieth Century. Nordicom Review, 28, 81-104

Dyer JR, W.G. (1994). Toward a theory of entrepreneurial careers. Entrepreneurship: Theory and Practice, 19(2), 7-22.

Elfving, J. (2008). Contextualizing Entrepreneurial Intentions: A Multiple Case Study on Entrepreneurial Cognitions and Perceptions. Turku, Finland: ÅboAkademiförlag.

Engle, R.L., Dimitriadi, N., Gavidia, J.V., Schlaegel, C., Delanoe, S., Alvarado, I. et al. (2010). Entrepreneurial intent: A twelve-country evaluation of Ajzen's model of planned behavior. International Journal of Entrepreneurial Behaviour \& Research, 16(1), 35-57. https://doi.org/10.1108/13552551011020063

Farrington, S.M., Venter, D.J.L., \& Louw, M.J. (2012). Entrepreneurial intentions: Demographic perspectives of South African business students. South African Journal of Business Management, 43(3), 41-49.

Fayolle, A., \& Gailly, B. (2004, July). Using the theory of planned behaviour to assess entrepreneurship teaching programs: A first experimentation. In Intent 2004 conference. Available online at: http://www.researchgate.net/publication/228752441

Fini, R., Grimaldi, R., Marzocchi, G.L., \& Sobrero, M. (2012). The determinants of corporate entrepreneurial intention within small and newly established firms. Entrepreneurship Theory and Practice, 36(2), 387-414. https://doi.org/10.1111/j.1540-6520.2010.00411.x

Fornell, C., \& Larcker, D.F. (1981). Evaluating structural equation models with unobservable variables and measurement error. Journal of marketing research, 18(1), 39-50. https://doi.org/10.2307/3151312

Gallurt Plá, P. (2010). Creación de «spin-offs» en las universidades españolas: Un modelo de intenciones. Doctoral dissertation, tesis doctoral. Sevilla, Departamento de Dirección de Empresas, Universidad Pablo de Olavide. 
Gatewood, E.J., Shaver, K.G., Powers, J.B., \& Gartner, W.B. (2002). Entrepreneurial expectancy, task effort, and performance. Entrepreneurship theory and practice, 27(2), 187-206. https://doi.org/10.1111/1540-8520.00006

George, D., \& Mallery, M. (2003). Using SPSS for Windows step by step: a simple guide and reference. Boston, MA: Allyn \& Bacon.

Gird, A., \& Bagraim, J.J. (2008). The theory of planned behaviour as predictor of entrepreneurial intent amongst final-year university students. South African Journal of Psychology, 38(4), 711-724. https://doi.org/10.1177/008124630803800410

González-Serrano, M.H., Valantine, I., Campos, C.P., Berenguer, S.A., Moreno, F.C., \& Hervás, J.C. (2016). La influencia del género y de la formación académica en la intención de emprender de los estudiantes de ciencias de la actividad física y el deporte. Intangible Capital, 12(3), 759-788. https://doi.org/10.3926/ic.783

Goyanes, M. (2015). Factors Affecting the Entrepreneurial Intention of Students Pursuing Journalism and Media Studies: Evidence from Spain. International Journal on Media Management, 17(2), 109-126. https://doi.org/10.1080/14241277.2015.1055748

Guerrero, M., Lavín, J., \& Álvarez, M. (2009). The role of education on start-up intentions: A structural equation model of Mexican university students. In 35th annual conference proceedings of the Association for Small Business and Entrepreneurship.

Guerrero, M., Rialp, J., \& Urbano, D. (2008). The impact of desirability and feasibility on entrepreneurial intentions: A structural equation model. International Entrepreneurship and Management Journal, 4(1), 35-50. https://doi.org/10.1007/s11365-006-0032-x

Harrison, G.W., \& List, J.A. (2004). Field experiments. Journal of Economic literature, 42(4), 1009-1055. https://doi.org/10.1257/0022051043004577

Henseler, J., Ringle, C.M., \& Sarstedt, M. (2015). A new criterion for assessing discriminant validity in variance-based structural equation modeling. Journal of the Academy of Marketing Science, 43(1), 115-135. https://doi.org/10.1007/s11747-014-0403-8

Jaén, I. (2010). Una revisión teórica de los valores en el estudio de la intención emprendedora. Trabajo de investigación. Sevilla: Universidad de Sevilla.

Jarvis, J. (2015). El fin de los medios de comunicación de masas. ¿Cómo serán las noticias del futuro?. Barcelona: Ediciones Gestión 2000. 
Kickul, J., Gundry, L.K., Barbosa, S.D., \& Whitcanack, L. (2009). Intuition versus analysis?. Testing differential models of cognitive style on entrepreneurial self-efficacy and the new venture creation process. Entrepreneurship Theory and Practice, 33(2), 439-453. https://doi.org/10.1111/j.15406520.2009.00298.x

Kickul, J., Krueger, N., \& Maxfield, S. (2005). Introduction: Special Issue on "Measurement Issues in Entrepreneurship Studies”. New England Journal of Entrepreneurship, 8(2), 2.

Kline, R.B. (2011). Principles and practice of structural equation modeling. New York: Guilford Press.

Kobeissi, N. (2010). Gender factors and female entrepreneurship: International evidence and policy implications. Journal of International Entrepreneurship, 8(1), 1-35. https://doi.org/10.1007/s10843-010-0045-y

Kolvereid, L., \& Isaksen, E. (2006). New business start-up and subsequent entry into self-employment. Journal of Business Venturing, 21(6), 866-885. https://doi.org/10.1016/j.jbusvent.2005.06.008

Krueger, N.F., \& Carsrud, A.L. (1993). Entrepreneurial intentions: Applying the theory of planned behaviour. Entrepreneurship \& Regional Development, 5(4), 315-330. https://doi.org/10.1080/08985629300000020

Krueger, N.F., Reilly, M.D., \& Carsrud, A.L. (2000). Competing models of entrepreneurial intentions. Journal of business venturing, 15(5), 411-432. https://doi.org/10.1016/S0883-9026(98)00033-0

Lee, S.H., \& Wong, P.K. (2004). An exploratory study of technopreneurial intentions: A career anchor perspective. Journal of Business Venturing, 19(1), 7-28. https://doi.org/10.1016/S0883-9026(02)00112-X

Leroy, H., Maes, J., Sels, L., Debrulle, J., \& Meuleman, M. (2009). Gender effects on entrepreneurial intentions: A Tab Multi Group Analysis at factor and indicator level. Paper presented at the Academy of Management Annual Meeting.

Liñán, F., \& Chen, Y.W. (2009). Development and Cross-Cultural application of a specific instrument to measure entrepreneurial intentions. Entrepreneurship theory and practice, 33(3), 593-617. https://doi.org/10.1111/j.1540-6520.2009.00318.x

Liñán, F., \& Santos, F.J. (2007). Does social capital affect entrepreneurial intentions?. International Advances in Economic Research, 13(4), 443-453. Available online at: http://hdl.handle.net/10.1007/s11294007-9109-8 https://doi.org/10.1007/s11294-007-9109-8

Liñán, F., Rodriguez-Cohard, J.C., \& Rueda-Cantuche, J.M. (2005). Factors affecting entrepreneurial intention levels. In 45th Congress of the European Regional Science Association, Amsterdam (pp. 23-27). Available online at: http://hdl.handle.net/10419/117622 
Liñán, F., Rodríguez-Cohard, J.C., \& Rueda-Cantuche, J.M. (2011). Factors affecting entrepreneurial intention levels: A role for education. International entrepreneurship and management Journal, 7(2), 195-218. https://doi.org/10.1007/s11365-010-0154-z

Lüthje, C., \& Franke, N. (2003). The 'making' of an entrepreneur: Testing a model of entrepreneurial intent among engineering students at MIT. R\&D Management, 33(2), 135-147. https://doi.org/10.1111/1467-9310.00288

Martínez, J., Mira, I., \& Gómez, J. (2010). Nascent Entrepreneurship and perceptual variables from a gender overview. Differences in different economic climates. In V Workshop de Investigación basada en GEM, Cádiz.

Palacios, L. (2015). Informe anual de la profesión periodística, 2015. Madrid, APM.

Peña, I., Guerrero, M., González-Pernía, J.L., Turró, A., Urbano, D., de Pablo, I. et al. (2016). Global Entrepreneurship Monitor. Informe GEM España 2015(Vol. 22). Ed. Universidad de Cantabria.

Prodan, I., \& Drnovsek, M. (2010). Conceptualizing academic-entrepreneurial intentions: An empirical test. Technovation, 30(5), 332-347. https://doi.org/10.1016/j.technovation.2010.02.002

Pruett, M., Shinnar, R., Toney, B., Llopis, F., \& Fox, J. (2009). Explaining entrepreneurial intentions of university students: A cross-cultural study. International Journal of Entrepreneurial Behavior \& Research, 15(6), 571-594. https://doi.org/10.1108/13552550910995443

Rigdon, E.E. (2016). Choosing PLS pathmodeling as analytical method in European management research: A realist perspective. European Management Journal, 34(6), 598.

https://doi.org/10.1016/j.emj.2016.05.006

Ringle, C.M., Wende, S., \& Will, A. (2005). SmartPLS 2.0 (M3) beta. Hamburg. Available online at: http://www.smartpls.de/

Sagie, A., \& Elizur, D. (1999). Achievement motive and entrepreneurial orientation: A structural analysis. Journal of Organizational Behavior, 20(3), 375-387. Available online at:

http://www.jstor.org/stable/3100296 https://doi.org/10.1002/(SICI)1099-1379(199905)20:3<375::AIDJOB884>3.0.CO;2-Y

Sahinidis, A.G., Giovanis, A.N., \& Sdrolias, L. (2012). The role of gender on entrepreneurial intention among students: An empirical test of the theory of planned behaviour in a Greek university. International Journal on Integrated Information Management, 1(1), 61-79. https://doi.org/10.15556/IJIIM.01.02.005 
Sánchez, J.C., Lanero, A., \& Yurrebaso, A. (2005). Variables determinantes de la intención emprendedora en el contexto universitario (Determinant Variables of theEntrepreneurial Intention in the University Context). Revista de Psicología Social Aplicada, 15(1), 37-60.

Shay, J., \& Terjensen, S. (2005). Entrepreneurial aspirations and intentions of business students: A gendered perspective. In Paper presentado en the Babson Entrepreneurship Conference, Boston, MA.

Shook, C.L., \& Bratianu, C. (2010). Entrepreneurial intent in a transitional economy: An application of the theory of planned behavior to Romanian students. International Entrepreneurship and Management Journal, 6(3), 231-247. https://doi.org/10.1007/s11365-008-0091-2

Souitaris, V., Zerbinati, S., \& Al-Laham, A. (2007). Do entrepreneurship programmes raise entrepreneurial intention of science and engineering students? The effect of learning, inspiration and resources. Journal of Business venturing, 22(4), 566-591. https://doi.org/10.1016/j.jbusvent.2006.05.002

Tenenhaus, M., Vinzi, V.E., Chatelin, Y.M., \& Lauro, C. (2005). PLS pathmodeling. Computational statistics \& data analysis, 48(1), 159-205. https://doi.org/10.1016/j.csda.2004.03.005

Ventura, R., \& Quero, M.J. (2013). Using Facebook in university teaching: A practical case study. Procedia-Social and Behavioral Sciences, 83, 1032-1038. https://doi.org/10.1016/j.sbspro.2013.06.192

White, K.M., Smith, J.R., Terry, D.J., Greenslade, J.H., \& McKimmie, B.M. (2009). Social influence in the theory of planned behaviour: The role of descriptive, injunctive, and in-group norms. British Journal of Social Psychology, 48(1), 135-158. https://doi.org/10.1348/014466608X295207

Wilson, F., Kickul, J., \& Marlino, D. (2007). Gender, entrepreneurial Self-Efficacy, and entrepreneurial careerintentions: Implications for entrepreneurship Education 1. Entrepreneurship theory and practice, 31(3), 387-406. https://doi.org/10.1111/j.1540-6520.2007.00179.x

Wurthmann, K. (2014). Business students' attitudes toward innovation and intentions to start their own businesses. International Entrepreneurship and Management Journal, 10(4), 691-711. https://doi.org/10.1007/s11365-013-0249-4

Zahra, S.A., Gedajlovic, E., Neubaum, D.O., \& Shulman, J.M. (2009). A typology of social entrepreneurs: Motives, search processes and ethical challenges. Journal of business venturing, 24(5), 519-532. https://doi.org/10.1016/j.jbusvent.2008.04.007

Zhao, H., Seibert, S.E., \& Hills, G.E. (2005). The mediating role of self-efficacy in the development of entrepreneurial intentions. Journal of applied psychology, 90(6), 1265. https://doi.org/10.1037/00219010.90.6.1265 


\section{Versión en español}

Título: Influencia del género en la intención emprendedora de los estudiantes de periodismo

\section{Resumen}

Objeto: El propósito de esta investigación es explicarla influencia del género en la formación de la intención emprendedora entre los futuros profesionales del periodismo. El estudio empírico se realiza en el marco de la Teoría del Comportamiento Planeado (TCP), donde se analizan las relaciones entre las variables actitud personal hacia el emprendimiento (AE), el control de la conducta percibida (CCP) y la influencia del entorno social de los emprendedores en la intención emprendedora (IE).

Diseño/metodología/enfoque: La investigación empírica se basa en un muestreo no aleatorio de conveniencia compuesto por 234 estudiantes de los últimos cursos del grado de Periodismo. Los modelos han sido testados mediante PLS (Partial Least Square).

Aportaciones y resultados: Los resultados indican la existencia de modelos explicativos de la intención emprendedora diferentes para hombres y mujeres. En este sentido, se destaca la relación significativa de la evaluación social sobre la intención emprendedora en el caso de las mujeres a diferencia de lo que ocurre en los hombres. Los resultados indican que las mujeres requieren más apoyo del entorno para emprender.

Limitaciones: El estudio empírico ser realiza con estudiantes de los cursos superiores de periodismo, y aunque la teoría del comportamiento planeado es bastante sólida, no se pueden generalizar los resultados a los profesionales del sector.

Implicaciones prácticas: Investigaciones como la presente ayudan a identificar los antecedentes sobre los que actuar y que hay que desarrollar en los programas formativos de los futuros periodistas. Desde el punto de vista de la investigación este estudio revela la utilidad de la TCP y añade evidencias sobre la validez explicativa del modelo.

Implicaciones sociales: Mejorar la inserción laborar de los profesionales del sector de la comunicación, prestando atención a las diferencias entre hombres y mujeres a la hora de considerar el emprendimiento como una opción profesional. 
Originalidad / Valor añadido: Se trata del primer estudio de esta naturaleza realizado en el contexto de la comunicación y de los pocos realizados en estudiantes no relacionados con el área de la economía y la empresa. Del mismo modo se trata de una profesión que tradicionalmente ha estado ligada al trabajo por cuenta ajena y que en el contexto actual de crisis se está reinventando y desarrollando a través del emprendimiento.

Palabras clave: Periodismo, Intención emprendedora, Género, Estudiantes, Teoría del Comportamiento Planeado, Modelos de ecuaciones estructurales, PLS

Códigos JEL: I23, L82, J26

\section{Introducción}

La irrupción de la tecnología digital en todas las esferas del negocio de la comunicación (producción, distribución y consumo) están provocando cambios drástico en los medios de comunicación (Jarvis, 2015). Esto ha llevado a que muchos comunicadores se vean abocados a desarrollar la actividad informativa por cuenta propia, bien sea trabajando como freelance o creando su propio medio.

En España el impacto de estas transformaciones ha sido particularmente duro. Según el Informe Anual de la Profesión Periodística editado por la Asociación de la Prensa de Madrid (APM) (Palacios, 2015) entre 2008 y 2015, se han destruido 12,200 empleos y se han cerrado 375 medios de comunicación. Del mismo modo, las condiciones laborales han empeorado: el salario medio base de los comunicadores con convenio se ha reducido un $17 \%$ desde el año 2010 y el 25\% de los periodistas autónomos han experimentado una caída de sus ingresos del 70\%.

En consecuencia los periodistas consideran que los dos principales problemas de la profesión son "el aumento del paro y la precariedad laboral" y "la mala retribución del trabajo periodístico". Si se analizan las condiciones laborales de las mujeres periodistas se observa que el $62.5 \%$ de las contratadas cobra menos de $1000 €$ frente al $46.4 \%$ de los hombres y que existe un techo de cristal para el acceso a los puestos directivos, tan solo hay un $15.9 \%$ de mujeres los ocupa, porcentaje que se mantiene constante en el tiempo desde antes de la crisis (Caro-González, García-Gordillo, Rodriguez-Rad \& JiménezMarín, 2007). 
En este contexto un tercio de los periodistas señalan que se han visto forzados a ser autónomos (Palacio, 2015). Cabría suponer que la mayoría de esos autónomos deberían ser mujeres, ya que las condiciones laborales precarias son un incentivo para el trabajo por cuenta propia (Dyer, 1994). Crear su propio negocio les permitiría quebrar el techo de cristal, accediendo a remuneraciones más igualitarias y a puestos directivos en las organizaciones. Sin embargo, en el citado Informe de la APM (Palacio, 2015) se observa que tan solo el 40.3\% de los trabajadores por cuenta propia son mujeres. Este dato no se comprende si se tiene en cuenta que entre 2011 y 2014 se licenciaron en España 15.807 periodistas de los que más del 65\% son mujeres. Esta información se alinea con los datos del informe GEM (Global Entrepreneurship Monitor) España (Peña et al., 2016, pp. 126), donde el 58.5\% de los emprendedores nacientes y nuevos son hombres.

Con el ánimo de comprender las razones de un menor emprendimiento en las mujeres cabe preguntarse si existen diferencias en las variables explicativas del mismo. Descubrir estas diferencias puede ayudar a diseñar programas de incentivación y formación en emprendimiento que mejoren el ratio de participación femenino en las actividades emprendedoras (Díaz-García \& Jiménez-Moreno, 2010).

Los investigadores prestan atención a la intención emprendedora porque es un predictor del comportamiento. Martínez, Mira y Gómez (2010) y Ventura y Quero (2013) consideran muy relevante la comprensión de la intención emprendedora para indagar sobre las razones del menor emprendimiento en la población femenina. El emprendedor se caracteriza por su capacidad de detectar oportunidades en el entorno y de innovar para aprovecharlas. Este proceso es intencional, por lo que el desarrollo de esta intención se puede considerar el primer paso en la creación de una nueva empresa (Crant, 1996; Krueger \& Carsrud, 1993; Lee \& Wong, 2004). Un incremento de la intención emprendedora derivaría posteriormente en un aumento del emprendimiento (Ajzen, 2005).

La consideración del género en este campo arroja resultados confusos. Una parte de los investigadores le otorgan escasa importancia a la hora de explicar la intención de crear un negocio (Armitage \& Conner, 2001; Pruett, Shinnar, Toney, Llopis \& Fox 2009). Opinan que el género de la persona no influye en la intención de emprender y es utilizada como una variable de control.

Sin embargo, hay otros investigadores que argumentan que la influencia del género no se percibe porque las aproximaciones metodológicas y teóricas son inadecuadas y, por tanto, la influencia del género en la intención emprendedora no ha sido estudiada a fondo y requiere de más estudios antes de llegar a conclusiones definitivas (Shay \& Terjesen, 2005; Shook \& Bratianu, 2010; Kobeissi, 2010). El 
efecto indirecto del género en la intención emprendedora es explicado en pocas investigaciones (Kickul, Krueger \& Maxfield, 2005; Wilson, Kickul \& Marlino, 2007; Goyanes, 2015)

Con esta investigación queremos aportar nuevas evidencias empíricas sobre el tema, analizando la intención emprendedora bajo la perspectiva de género en el caso de los estudiantes de periodismo. Se utiliza la Teoría del Comportamiento Planeado (TCP), con el fin de entender mejor en qué medida el género influye en la intención emprendedora (IE) y sus antecedentes. Dicha teoría es el modelo más utilizado para el estudio de las intenciones emprendedoras (Arias, Restrepo \& Restrepo, 2016) y ha dado lugar a resultados generalmente aceptados, explicando una cantidad de varianza de la IE en un rango que va de 0.27 a 0.65 (Armitage \& Conner, 2001; Ajzen, 2005).

El modelo TCP es testado en una población de 234 estudiantes de los últimos cursos del grado de periodismo. Los resultados se obtienen a partir de modelos de ecuaciones estructurales analizados con el programa PLS.

La estructura del artículo es la siguiente. En primer lugar se describe el modelo de la Teoría del Comportamiento Planeado que sirve de base para el estudio. A continuación se explica la metodología utilizada, PLS (Partial Least Square). Finalmente se aportan los resultados y se confrontan con la literatura previa. Para finalizar se señalan las aportaciones teóricas y metodológicas más relevantes y sus implicaciones para la formación de los futuros profesionales del periodismo en la actitud emprendedora.

\section{Marco teórico}

Para conocer el impacto del género sobre la intención de emprender en los futuros profesionales del periodismo se emplea la Teoría del Comportamiento Planeado (TCP) (Ajzen, 1991). La premisa básica de esta teoría es que hay un vínculo fuerte entre la intención de actuar y el comportamiento real. Armitage y Conner (2001), en un metanálisis de 185 investigaciones usando el modelo TCP, comprobaron que esta teoría podía explicar el 27\% de la varianza del comportamiento y un 39\% de la intención emprendedora.

La literatura sobre la intención emprendedora (IE) pone de manifiesto la utilidad de la TCP al demostrar que existe un vínculo entre los antecedentes de la IE y la propia intención y el comportamiento (Krueger, Reilly \& Carsrud, 2000; Guerrero, Rialp \& Urbano, 2008). 
El modelo TCP puede observarse en la Figura 1. La variable dependiente es la intención emprendedora (IE) y las independientes la actitud hacia el emprendimiento (AE), el control conductual percibido (CCP), las normas sociales (NS) y la evaluación social (ES).

La intención emprendedora (IE) constituye la clave para entender el proceso emprendedor. "Una persona desarrolla una intención para realizar cierto comportamiento, esta intención permanece como una disposición hasta que, en el tiempo apropiado y la oportunidad, el intento se transforma en una acción" (Ajzen, 2005). En nuestro caso la IE representa un constructo que conecta el proceso de detectar una oportunidad con el hecho de llevarla a cabo (Dimov, 2007; Carsrud \& Brännback, 2011). Esta variable es una de las precursoras más viables del comportamiento emprendedor que dará lugar a la creación de nuevos negocios (Prodan \& Drnovsek, 2010).

El control del comportamiento percibido (CCP) es otra variable latente que desempeña un papel capital en la predicción de la IE y el comportamiento emprendedor en comunicación. Este constructo refleja la percepción de la capacidad que tiene el individuo para crear y dirigir una nueva empresa (Jaén, 2010). Los investigadores varían en el uso del término y utilizan con frecuencia de forma indistinta CCP y autoeficacia, o introducen pequeños matices que diferencian a estos términos (Krueger et al., 2000). Autores como Armitage y Conner (2001) y Pruett et al. (2009) encontraron un vínculo significativo entre la CCP y la IE. Sin embargo, en el trabajo multicultural de Engle et al. (2010) se obse rvó que la relación entre la CCP y la IE solo fue significativa en siete de los doce países investigados. Por lo que sigue siendo interesante estudiar esta relación en contextos diferenciados como es el caso singular de estudiantes de periodismo en España.

En cualquier caso el constructo CCP se encuentra entre los predictores más fuertes de la IE junto con la AE y su uso es recurrente para explicar la IE (Ajzen, 2005).

La actitud hacia el emprendimiento (AE) constituye el tercer constructo del modelo. Se trata de un factor personal que señala el deseo del individuo para crear valor desplegando un comportamiento emprendedor (Fini, Grimaldi, Marzocchi \& Sobrero, 2012). La correlación positiva y directa con la IE ha sido puesta de manifiesto en diversas investigaciones (Engle et al., 2010; Liñán, Rodríguez-Cohard \& Rueda-Cantuche, 2011)

Otros constructos que ayudan a entender los antecedentes de la intención emprendedora son las normas sociales (NS) y la evaluación social (ES). Se trata de conocer en qué medida influye el entorno próximo del individuo en su comportamiento a la hora de emprender (White, Smith, Terry, Greenslade \& McKimmie, 2009). En la medida en que el entorno social valore la actividad empresarial y se 
considere que se tienen los conocimiento y aptitudes necesarios, las personas estarán más motivadas y se sentirán capaces de comenzar un negocio (Gallurt Plá, 2010)

En este caso, la influencia sobre el futuro emprendedor depende de los padres, los amigos y otras personas que de alguna forma pueden promover o desaprobar la idea de emprender. Algunas investigaciones confirman que las normas sociales afectan directamente a la IE (Pruett et al., 2009; Engle et al., 2010). Sin embargo, Shook y Bratianu (2010) encontraron una relación negativa entre las normas de contexto y la IE. También Krueger et al. (2000) y Armitage y Conner (2001) constataron una relación débil entre las dos variables. En este sentido es interesante aportar otras investigaciones que contribuyan a discernir este debate.

Finalmente, Ajzen (2005) y Guerrero, Lavin y Álvarez (2009) encontraron un efecto indirecto de las normas sociales y valoraciones en la IE con la mediación de AE y CCP. La presión social tiende a promover una actitud favorable hacia el emprendimiento y también pueden aumentar el CCP impactando así en la IE. Zahra, Gedajlovic, Neubaum y Shulman (2009) consideran determinante el impacto de la cultura, definida a través de la evaluación social y las normas sociales en el comportamiento empresarial.

Como se observa, a pesar del apoyo recibido en la literatura, los resultados de los trabajos que emplean la TCP no siempre han coincidido. Así, mientras que Gird y Bagraim (2008) señalaron una relación significativa entre los tres antecedentes de la IE y la intención de iniciar un negocio, Liñán y Chen (2009), demuestran que no hay ningún vínculo entre la IE y las normas sociales, corroborando los hallazgos previos de Krueger et al. (2000). Engle et al. (2010), en su investigación con muestras procedentes de doce países, encontraron que en la mitad de estos, los predictores de la IE eran las normas sociales y el deseo de emprender, mientras que en la otra mitad, fueron las normas sociales y el control del comportamiento percibido.

La repercusión de este último trabajo apunta en la dirección de llevar a cabo estudios más específicos usando la TCP en lugar de tratar de identificar modelos de aplicación universal. Las investigaciones son muy homogéneas y no han tenido en cuenta factores contextuales (Elfving, 2008; Kickul, Gundry, Barbosa \& Whitcanack, 2009). Además como señala Alonso-García (2012) buena parte de las investigaciones están basadas en datos recolectados en Estados Unidos y hay pocos trabajos internacionales que comparen diferentes entornos sociales y culturales, con algunas excepciones (De Pillis \& Reardon, 2007; Delmar \& Davidsson, 2000; Liñán \& Chen, 2009). Con esta investigación se 
quiere aportar evidencias sobre el modelo TCP aplicado al emprendimiento en el sector concreto de la comunicación.

\section{Objetivos e hipótesis}

El objetivo de esta investigación es analizar la intención emprendedora en estudiantes de periodismo bajo la perspectiva de género y en el marco de la Teoría del Comportamiento Planeado. De esta forma se puede constatar la validez del modelo en el caso de los estudiantes de periodismo e identificar diferencias significativas en el modelo según el sexo de la persona encuestada.

Como se ha descrito en el marco teórico, el modelo TCP mide la intención emprendedora (IE) a partir de las variables comportamiento conductual percibido (CCP), actitud al emprendimiento (AE). Esta propuesta se enriquece con dos antecedentes, por una parte las normas sociales (NS) y por otra la evaluación social del emprendimiento (ES).

El modelo TCP que se va a analizar se muestra en la Figura 1.

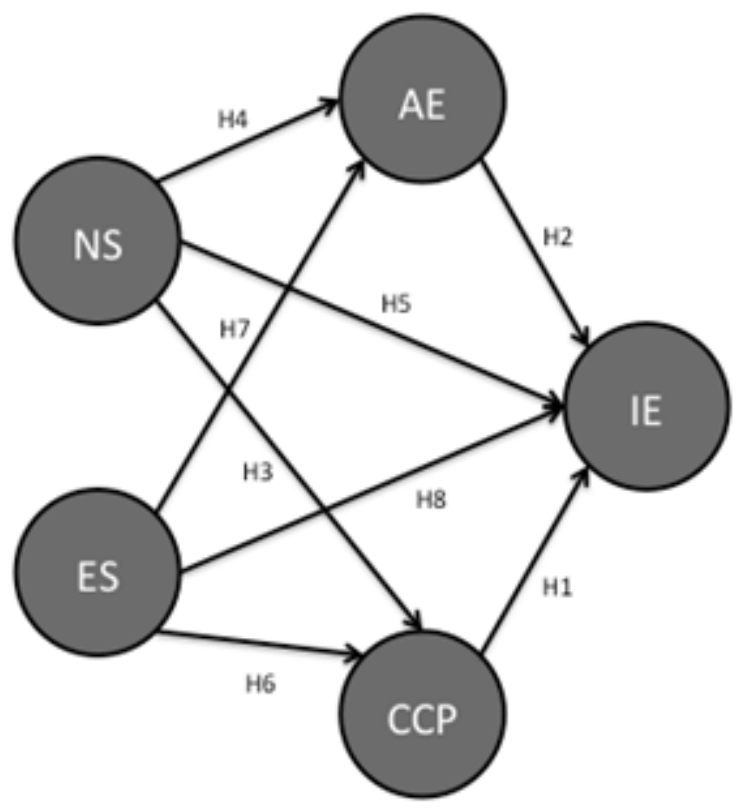

Figura 1. Modelo propuesto e hipótesis. 
En función del análisis teórico previo se proponen las siguientes hipótesis:

H1: CCP se relaciona positivamente con IE.

H2: AE se relaciona positivamente con IE.

H3: NS se relaciona positivamente con CCP.

H4: NS se relaciona positivamente con AE.

H5: NS se relaciona positivamente con IE.

H6: ES se relaciona positivamente con CCP.

H7: ES se relaciona positivamente con $A E$.

H8: ES se relaciona positivamente con IE.

Del mismo modo, si se contempla el sexo del alumnado, se pueden esperar diferencias entre los modelos explicativos de la intención emprendedora.

\section{Metodología, análisis y resultados}

La investigación empírica se basa en un muestreo no aleatorio de conveniencia. En particular, los datos fueron recolectados a través de un cuestionario enlazado a la página de Facebook de las asignaturas de creación de empresas de la Facultad de Comunicación de la Universidad de Sevilla. El universo de los estudiantes es un contexto muy utilizado en este tipo de investigaciones (Krueger et al., 2000; Lüthje \& Franke, 2003; Fayolle \& Gailly, 2004; Souitaris, Zerbinati \& Al-Laham, 2007; Ventura \& Quero, 2013). La literatura ha evidenciado varios motivos que avalan el uso de esta población para analizar las intenciones emprendedoras (Arias et al., 2016). Entre ellos se destaca que los alumnos universitarios están próximos a enfrentarse a la decisión sobre su futuro profesional, por lo que las manifestaciones en cuanto a intenciones son meditadas (Liñán \& Santos, 2007). Constituyen, por tanto, un grupo potencialmente emprendedor (Sánchez, Lanero \& Yurrebaso, 2005) que es considerado como representativo de la población para analizar el comportamiento humano (Harrison \& List, 2004).

El cuestionario ha sido aplicado al inicio de las asignaturas a todos los alumnos matriculados durante los cursos 2013-14, 2014-15 y 2015-16. El número final de estudiantes encuestados, una vez depurados 
los inválidos, ha sido de 234. La composición por sexo de esta muestra es acorde con el universo explorado (un $69.27 \%$ de estudiantes mujeres y un 30.73\% de estudiantes hombres).

Las preguntas del cuestionario se han obtenido de escalas testadas previamente en diferentes investigaciones. En particular se ha adaptado el cuestionario empleado por Sahinidis, Giovanis y Sdrolias (2012) que fue construido a partir de los instrumentos creados por Liñán y Chen (2009) y Guerrero et al. (2009).

\subsection{Valoración del Modelo de Investigación}

Para testar el modelo de investigación se usó un enfoque Partial Least Squares (PLS) para modelos de ecuaciones estructurales (SEM) (Chin, 1998; Tenenhaus, Vinzi, Chatelin \& Yves-Marie, 2005).

Las razones para el empleo de PLS frente a otros tipos de programas estadísticos de modelización con ecuaciones estructurales son (Diamantopoulos \& Winklhofer, 2001; Rigdon, 2016):

- la naturaleza exploratoria de este trabajo,

- PLS no requiere de grandes muestras, frente a otros programas estadísticos (AMOS, EQS, etc.), para la obtención de resultados;

- PLS es una técnica no paramétrica, por lo que no es necesario garantizar la normalidad de los datos.

Se ha valorado el modelo propuesto para cada uno de los grupos, el femenino (G1) y el masculino (G2).

Un modelo de ecuaciones estructurales es descrito por dos modelos:

- un modelo de medida entre las variables manifiestas (VMs) y sus propias variables latentes (VLs) y

- un modelo estructural de las relaciones entre las variables endógenas y exógenas.

En las Figuras 2 y 3 se puede observar el modelo en el G1 y G2 una vez aplicado el algoritmo PLS (Ringle, Wende \& Will, 2005) y depurados aquellos indicadores cuyo landa es inferior a 0.7 en cualquiera de los dos modelos (pa1, sn3, sv3, pbc1, pbc4, pbc5).De esta manera se garantiza que la 
varianza compartida entre el constructo y sus indicadores es mayor que la varianza debida al error (Carmines \& Zeller, 1979).

De forma que el modelo resultante es válido tanto para el G1 como para el G2 sería:

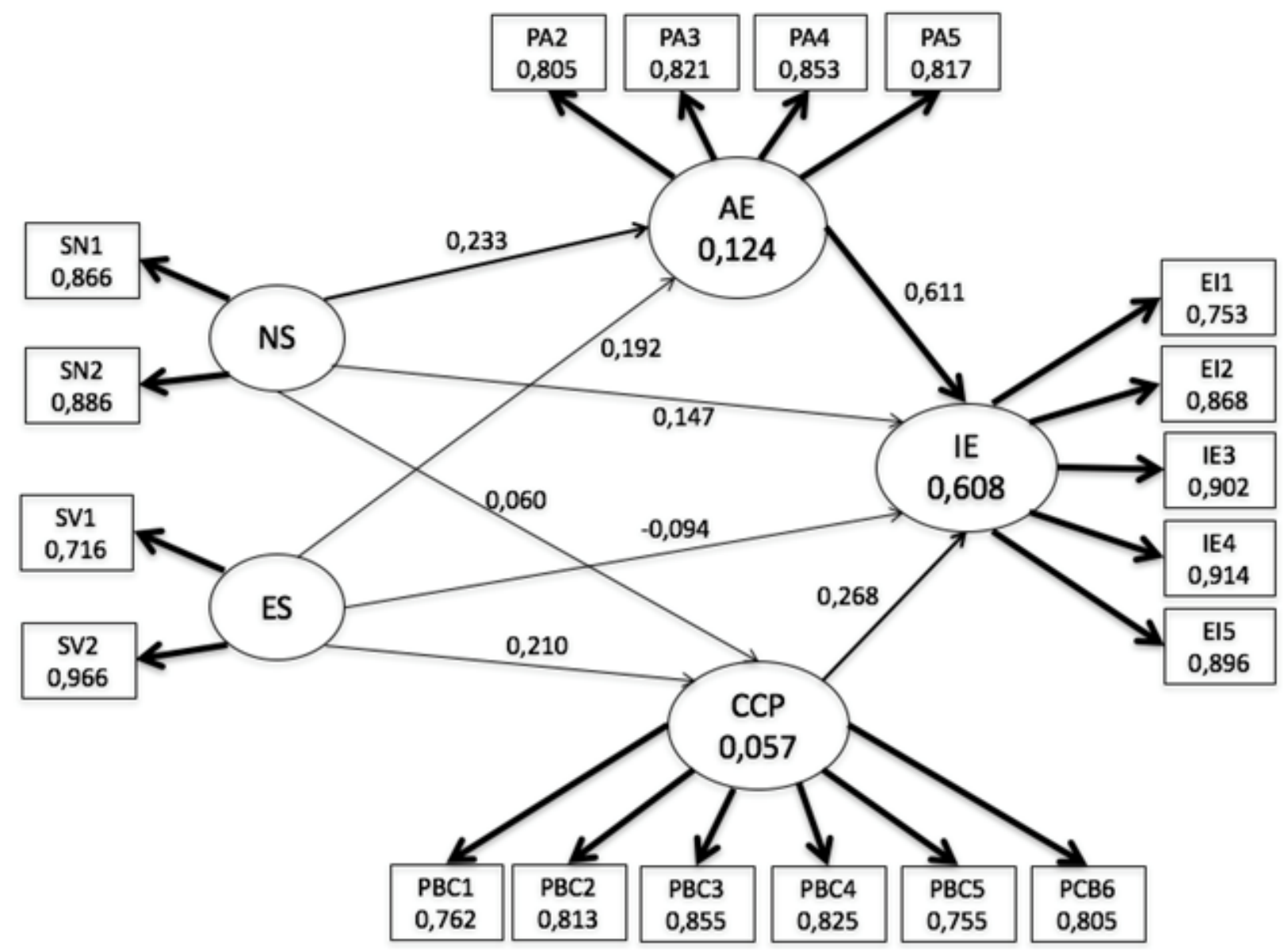

Figura 2. Modelo R-cuadrado y camino estimado del análisis PLS para G1 (mujeres) 


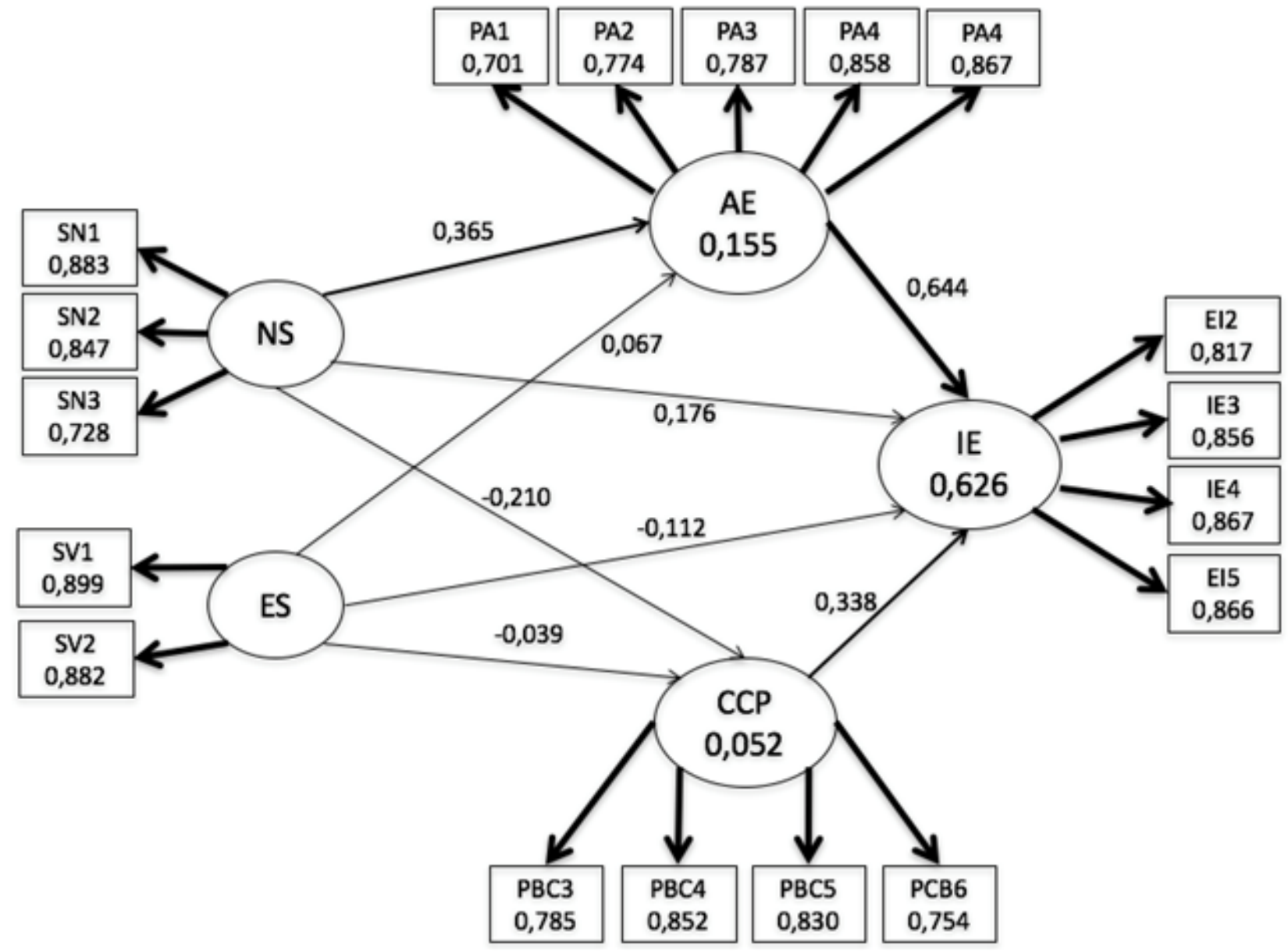

Figura 3. Modelo R-cuadrado y camino estimado del análisis PLS para G2 (hombres)

\subsection{Análisis del Modelo de Medida}

La fiabilidad y validez de los modelos de medida fueron determinadas previamente al análisis del modelo estructural. La fiabilidad individual de cada indicador se evaluó examinado las cargas $(\lambda)$ o correlaciones simples con sus respectivas variables latentes (VL). Se aceptaron los indicadores con $\lambda \geq$ 0.707. Además, los indicadores deben correlacionarse más fuertemente con su propio constructo que con cualquier otro (Fornell \& Larcker, 1981).

En la Tabla 1 se muestran los resultados del procedimiento de carga cruzada del grupo 1 y del grupo 2. 


\begin{tabular}{|c|c|c|c|c|c|c|c|c|c|c|}
\hline & \multicolumn{5}{|c|}{ G1 Mujer } & \multicolumn{5}{|c|}{ G2 Hombre } \\
\hline & AE & CCP & ES & IE & NS & AE & CCP & ES & IE & NS \\
\hline ei1 & 0.420 & 0.498 & 0.163 & 0.753 & 0.297 & - & - & - & - & - \\
\hline ei2 & 0.654 & 0.365 & 0.180 & 0.868 & 0.375 & 0.667 & 0.32 & 0.069 & 0.817 & 0.173 \\
\hline ei3 & 0.722 & 0.425 & 0.160 & 0.902 & 0.299 & 0.639 & 0.227 & 0.012 & 0.856 & 0.4 \\
\hline ei4 & 0.675 & 0.414 & 0.195 & 0.914 & 0.248 & 0.507 & 0.302 & 0.016 & 0.867 & 0.277 \\
\hline ei5 & 0.654 & 0.467 & 0.139 & 0.896 & 0.243 & 0.589 & 0.336 & 0.024 & 0.866 & 0.209 \\
\hline pa1 & - & - & - & - & - & 0.701 & 0.176 & 0.11 & 0.52 & 0.15 \\
\hline pa2 & 0.805 & 0.184 & 0.248 & 0.562 & 0.256 & 0.774 & -0.095 & 0.268 & 0.514 & 0.414 \\
\hline pa3 & 0.821 & 0.222 & 0.271 & 0.599 & 0.256 & 0.787 & -0.107 & 0.072 & 0.532 & 0.437 \\
\hline pa4 & 0.853 & 0.358 & 0.24 & 0.585 & 0.241 & 0.858 & 0.049 & 0.186 & 0.583 & 0.283 \\
\hline pa5 & 0.817 & 0.454 & 0.161 & 0.653 & 0.248 & 0.867 & 0.221 & 0.137 & 0.683 & 0.248 \\
\hline pbc1 & 0.405 & 0.762 & 0.191 & 0.389 & 0.178 & - & - & - & - & - \\
\hline pbc2 & 0.259 & 0.813 & 0.173 & 0.410 & 0.155 & - & - & - & - & - \\
\hline pbc3 & 0.340 & 0.855 & 0.215 & 0.472 & 0.144 & 0.039 & 0.785 & -0.079 & 0.248 & -0.152 \\
\hline pbc4 & 0.235 & 0.825 & 0.248 & 0.298 & 0.065 & 0.101 & 0.852 & -0.053 & 0.257 & -0.323 \\
\hline pbc5 & 0.248 & 0.755 & 0.195 & 0.274 & 0.01 & -0.057 & 0.83 & -0.12 & 0.23 & -0.211 \\
\hline pbc6 & 0.285 & 0.805 & 0.114 & 0.473 & 0.074 & 0.088 & 0.754 & -0.117 & 0.381 & -0.016 \\
\hline sn1 & 0.222 & 0.167 & 0.238 & 0.290 & 0.866 & 0.356 & -0.226 & 0.33 & 0.27 & 0.883 \\
\hline $\operatorname{sn} 2$ & 0.307 & 0.078 & 0.404 & 0.295 & 0.886 & 0.246 & -0.138 & 0.28 & 0.25 & 0.847 \\
\hline $\operatorname{sn} 3$ & - & - & - & - & - & 0.338 & -0.175 & 0.242 & 0.244 & 0.728 \\
\hline sv1 & 0.122 & 0.094 & 0.716 & 0.060 & 0.277 & 0.192 & -0.069 & 0.899 & 0.074 & 0.301 \\
\hline sv2 & 0.297 & 0.251 & 0.966 & 0.214 & 0.353 & 0.153 & -0.134 & 0.882 & -0.012 & 0.32 \\
\hline
\end{tabular}

Tabla 1. Resultados del procedimiento de carga cruzada del grupo 1 y 2

La fiabilidad de la VL indica la rigurosidad con que las variables observadas la miden. La fiabilidad compuesta fue utilizada como el índice de fiabilidad de las VLs (fueron aceptadas VLs con $\alpha>0.7$ ). La validez convergente de la VL se evaluó mediante el examen de la varianza media extraída (AVE), véase Fornell y Larcker (1981) (se aceptaron AVE> 0.5). La Tabla 2 muestra la fiabilidad compuesta, el AVE y el Alfa de Cronbach por cada VL. Este último es adecuado en todos los constructos en caso del grupo 2. En el grupo 1 los constructos ES y NS está muy próximo a 0.7 lo que se considera un valor aceptable (George \& Mallery, 2003, pp. 231).

\begin{tabular}{|l|r|r|r|r|r|r|}
\cline { 2 - 7 } \multicolumn{1}{c|}{} & \multicolumn{3}{c|}{ G1 Mujer } & \multicolumn{3}{c|}{ G2 Hombre } \\
\cline { 2 - 7 } \multicolumn{1}{c|}{} & $\begin{array}{c}\text { Fiabilidad } \\
\text { compuesta }\end{array}$ & AVE & $\begin{array}{c}\text { Alfa de } \\
\text { Cronbach }\end{array}$ & $\begin{array}{c}\text { Fiabilidad } \\
\text { compuesta }\end{array}$ & AVE & $\begin{array}{c}\text { Alfa de } \\
\text { Cronbach }\end{array}$ \\
\hline AE & 0.894 & 0.679 & 0.842 & 0.898 & 0.640 & 0.858 \\
\hline PBC & 0.916 & 0.645 & 0.891 & 0.881 & 0.650 & 0.820 \\
\hline ES & 0.836 & 0.723 & 0.677 & 0.884 & 0.793 & 0.739 \\
\hline EI & 0.939 & 0.755 & 0.918 & 0.913 & 0.725 & 0.874 \\
\hline SN & 0.869 & 0.768 & 0.698 & 0.861 & 0.676 & 0.757 \\
\hline
\end{tabular}

Tabla 2. Fiabilidad compuesta y AVE 
Se probó la validez discriminante de las variables latentes analizando si la raíz cuadrada del AVE de cada VL es mayor que las correlaciones con el resto de las VLs (ver la Tabla 3).

\begin{tabular}{|l|l|l|r|r|r|r|r|r|r|r|}
\cline { 2 - 12 } \multicolumn{1}{c|}{} & \multicolumn{4}{c|}{ G1 Mujer } & \multicolumn{5}{c|}{ G2 Hombre } \\
\cline { 2 - 12 } \multicolumn{1}{c|}{} & AE & CCP & \multicolumn{1}{c|}{ ES } & IE & NS & AE & CCP & ES & IE & NS \\
\hline AE & 0.824 & & & & & 0.8 & & & & \\
\hline CCP & 0.373 & 0.803 & & & & 0.058 & 0.806 & & & \\
\hline ES & 0.278 & 0.232 & 0.85 & & & 0.194 & -0.113 & 0.89 & & \\
\hline IE & 0.729 & 0.493 & 0.192 & 0.869 & & 0.711 & 0.348 & 0.036 & 0.852 & \\
\hline NS & 0.304 & 0.138 & 0.37 & 0.334 & 0.876 & 0.389 & -0.224 & 0.348 & 0.312 & 0.822 \\
\hline
\end{tabular}

Tabla 3. Correlaciones de VL para el grupo 1 y 2 (elementos en la diagonal son las raíces cuadradas del AVE)

Adicionalmente, se ha calculado la ratio heterotrait-monotrait (HTMT) que detecta mejor la falta de validez discriminante (Tabla 4) que el examen de cargas cruzadas y el criterio Fornell-Larcker (Henseler, Ringle \& Sarstedt, 2015). El ratio HTMT debe estar por debajo de 0.85 (Kline, 2011).

\begin{tabular}{|l|r|r|r|r|r|r|r|r|r|r|}
\cline { 2 - 12 } \multicolumn{1}{c|}{} & \multicolumn{4}{c|}{ G1 Mujer } & \multicolumn{6}{c|}{ G2 Hombre } \\
\cline { 2 - 12 } \multicolumn{1}{c|}{} & \multicolumn{1}{c|}{ AE } & CCP & ES & IE & NS & AE & CCP & ES & IE & NS \\
\hline AE & & & & & & & & & & \\
\hline CCP & 0.42 & & & & & 0.194 & & & & \\
\hline ES & 0.32 & 0.276 & & & & 0.243 & 0.163 & & & \\
\hline IE & 0.818 & 0.538 & 0.2 & & & 0.813 & 0.41 & 0.093 & & \\
\hline NS & 0.394 & 0.181 & 0.524 & 0.421 & & 0.468 & 0.27 & 0.464 & 0.381 & \\
\hline
\end{tabular}

Tabla 4. Ratio heterotrait-monotrait (HTMT) para el grupo 1 y 2

Los trabajos previos en los que se basó el presente estudio (Sahinidis et al., 2012; Liñán \& Chen, 2009; Guerrero et al., 2009) obtuvieron resultados similares en la validación de la escala de medida del modelo. Concretamente, lograron un alfa de Cronbach superiores a 0.7 y las variables de medidas estaban altamente correlacionadas con los constructos a los que pertenecían. 


\subsection{Análisis del Modelo Estructural}

Después de comprobar la validez y la fiabilidad del modelo de medida, se probaron las relaciones entre los constructos. Las hipótesis fueron contrastadas mediante el examen de los coeficientes de camino ( $\beta$ ) y sus niveles de significación (se aceptaron $\beta>=0.2$ ). Se realizó un bootstrapping con 500 sub-muestras para comprobar la significación estadística de cada uno de los coeficientes de los caminos. La varianza explicada $\left(\mathrm{R}^{2}\right)$ en las VLs endógenas y el coeficiente de significación de regresión (F-test), sirven como indicadores de la capacidad explicativa del modelo.

\begin{tabular}{|c|c|c|c|c|c|c|c|c|c|c|}
\hline & \multicolumn{5}{|c|}{ G1 Mujer } & \multicolumn{5}{|c|}{ G2 Hombre } \\
\hline & $\begin{array}{l}\text { Original } \\
\text { Sample } \\
\text { (O) }\end{array}$ & $\begin{array}{c}\text { Sample } \\
\text { Mean } \\
\text { (M) }\end{array}$ & $\begin{array}{l}\text { Standard } \\
\text { Deviation } \\
\text { (STDEV) }\end{array}$ & $\begin{array}{c}\text { T Statistics } \\
(|\mathrm{O} / \mathrm{STDEV}|)\end{array}$ & $\begin{array}{c}\mathbf{P} \\
\text { Values }\end{array}$ & $\begin{array}{c}\text { Original } \\
\text { Sample } \\
\text { (O) }\end{array}$ & $\begin{array}{c}\text { Sample } \\
\text { Mean } \\
\text { (M) }\end{array}$ & $\begin{array}{l}\text { Standard } \\
\text { Deviation } \\
\text { (STDEV) }\end{array}$ & $\begin{array}{l}\text { T Statistics } \\
(|\mathrm{O} / \mathrm{STDEV}|)\end{array}$ & $\begin{array}{c}\mathbf{P} \\
\text { Values }\end{array}$ \\
\hline $\mathrm{AE}->\mathrm{IE}$ & 0.611 & 0.613 & 0.05 & 12.325 & $0.000 *$ & 0.644 & 0.642 & 0.089 & 7.241 & $0.000 *$ \\
\hline CCP -> IE & 0.268 & 0.272 & 0.058 & 4.623 & $0.000 *$ & 0.337 & 0.34 & 0.09 & 3.732 & $0.000^{*}$ \\
\hline ES -> AE & 0.192 & 0.196 & 0.081 & 2.37 & $0.018^{*}$ & 0.067 & 0.087 & 0.133 & 0.505 & 0.614 \\
\hline $\mathrm{ES}->\mathrm{CCP}$ & 0.21 & 0.22 & 0.086 & 2.436 & $0.015^{*}$ & -0.039 & -0.03 & 0.165 & 0.238 & 0.812 \\
\hline ES -> IE & -0.094 & -0.096 & 0.055 & 1.724 & 0.085 & -0.112 & -0.112 & 0.077 & 1.456 & 0.146 \\
\hline $\mathbf{N S}->\mathbf{A E}$ & 0.233 & 0.244 & 0.094 & 2.47 & $0.014 *$ & 0.365 & 0.365 & 0.146 & 2.495 & $0.013^{*}$ \\
\hline NS $->$ CCP & 0.060 & 0.063 & 0.098 & 0.608 & 0.543 & -0.21 & -0.21 & 0.191 & 1.1 & 0.272 \\
\hline NS -> IE & 0.147 & 0.142 & 0.063 & 2.319 & $0.021 *$ & 0.176 & 0.176 & 0.101 & 1.733 & 0.084 \\
\hline
\end{tabular}

Tabla 5.Resultados de los análisis PLS para el G1 y el G2

Se observa en la Tabla 5 como las siguientes relaciones son significativas:

AE -> IE para ambos casos.

CCP -> IE para ambos casos.

ES -> AE solo en el G1.

ES -> CCP solo en el G1.

NS -> AE para ambos casos.

NS -> IE solo en el G1.

La varianza explicada para cada variable en ambos grupos sería (ver Tabla 6): 


\begin{tabular}{|l|r|r|}
\cline { 2 - 3 } \multicolumn{1}{c|}{} & \multicolumn{2}{c|}{ R Square } \\
\cline { 2 - 3 } \multicolumn{1}{c|}{ GE } & G1 Mujer & G2 Hombre \\
\hline CCP & 0.124 & 0.155 \\
\hline IE & 0.057 & 0.052 \\
\hline
\end{tabular}

Tabla 6. Varianza explicada $\left(\mathrm{R}^{2}\right)$ en las VLs endógenas

Con estos resultados, se soportan para el grupo 1 las hipótesis H1, H2, H4, H5, H6, H7 y para el grupo 2 las hipótesis H1, H2, H4.

En consecuencia podemos establecer que el modelo TCP quedaría de la siguiente manera (ver Figura 4):

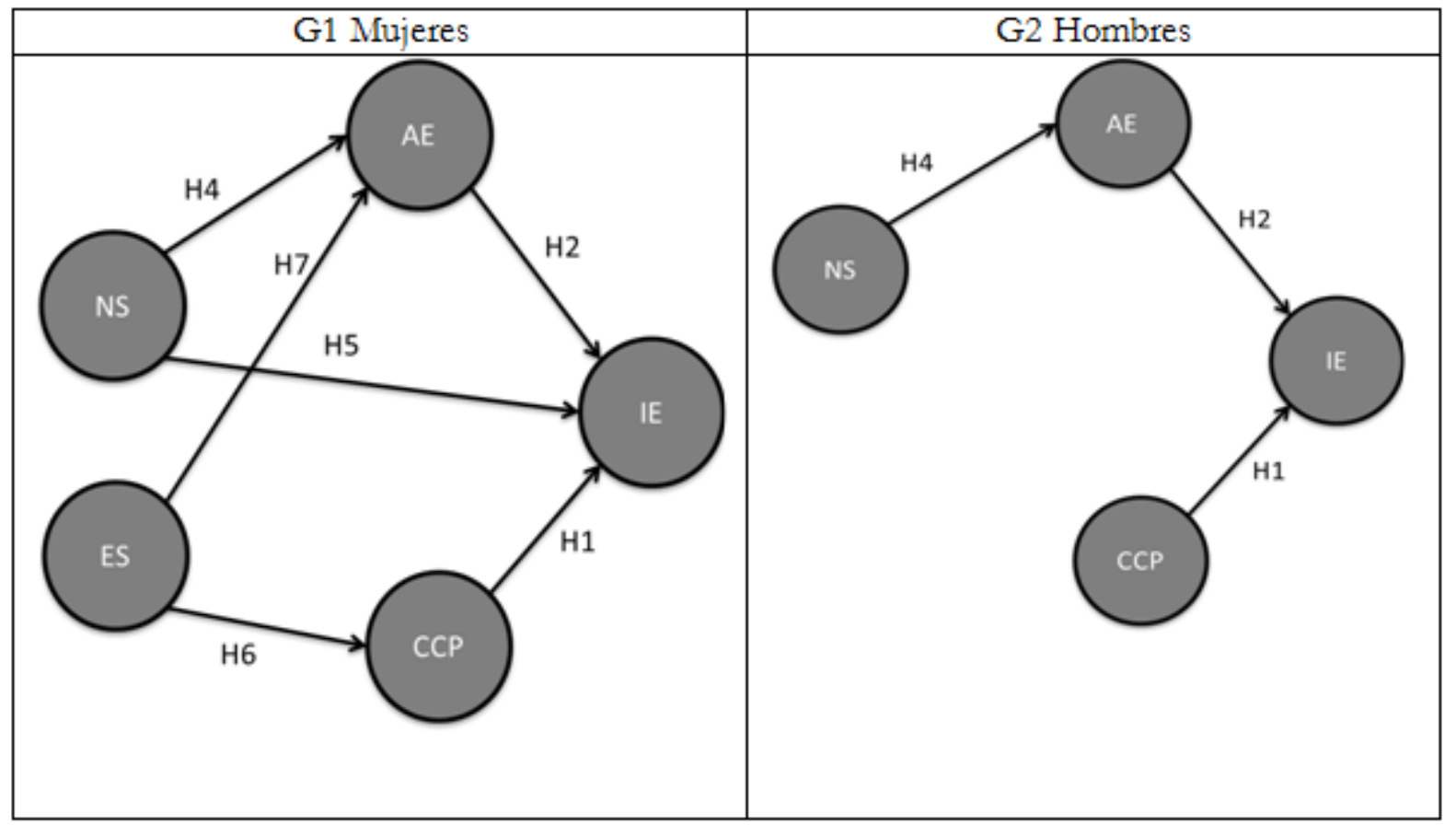

Figura 4. Modelo final TCP 


\section{Conclusiones}

El modelo de la Teoría del Comportamiento Planeado es una herramienta útil para explicar la intención emprendedora en estudiantes de periodismo que carecen de formación empresarial. La mayoría de los estudios existentes sobre este tema han analizado estos constructos en alumnos de carreras relacionadas con el mundo de la empresa (Sagie \& Elizur, 1999; DeMartino \& Barbato, 2002; Krueger et al., 2000; Gatewood, Shaver, Powers \& Gartner, 2002; Lüthje \& Franke, 2003; Liñán, Rodriguez-Cohard \& Rueda-Cantuche, 2005; Wilson et al. 2007; Zhao, Seibert \& Hills, 2005; Sahinidis et al., 2012; Wurthmann, 2014). En este caso, además, se trata de estudiantes que afrontan un contexto económico de crisis y cambio donde el emprendimiento es fundamental para su desarrollo profesional. Se comprueba la robustez del modelo TCP para explicar la intención emprendedora de los futuros profesionales de la comunicación, tanto en el caso de los hombres como en el de las mujeres, alcanzando una varianza explicada de 0.626 y 0.608 respectivamente.

El modelo de medida y el modelo estructural son válidos. Sin embargo, se aprecian diferencias en cuanto a las relaciones significativas entre constructos, poniéndose de manifiesto que, en el caso de las mujeres, las variables exógenas NS y ES tienen impacto tanto directo (NS) como indirecto (NS y ES) sobre la intención emprendedora, algo que no ocurre en el caso de los hombres, donde la intención emprendedora solo recibe impacto indirecto de NS. En la revisión de la literatura se encuentran resultados opuestos, hay estudios que indican que no se ha podido establecer una relación directa entre las normas subjetivas y la intención emprendedora (Krueger et al., 2000), mientras que otros demuestran que sí existe tal relación y que ésta es positiva (Kolvereid \& Isaksen, 2006). Puede que la respuesta a esta controversia se encuentre en el sexo de la población encuestada. Diferentes investigaciones indican que existe una importante relación entre el género y la IE (Farrington, Venter \& Louw, 2012; Gird \& Bagraim, 2008; Engle et al., 2010, Sahinidis et al., 2012, Goyanes, 2015). Más específicamente, se refuerzan algunos de los estudios que encontraron que los factores del entorno apenas tienen influencia en los hombres pero sí en las mujeres (Leroy, Maes, Sels, Debrulle \& Meuleman, 2009). En este sentido González-Serrano, Valantine, Campos, Berenguer, Moreno y Hervás (2016) observaron que las estudiantes de ciencias de la actividad física y el deporte valoran la norma social con una puntuación más elevada que los hombres. En el caso de los estudiantes de periodismo varones las relaciones con una de las variables del entorno no son significativas.

La percepción que tienen las mujeres, futuras profesionales del periodismo, sobre cómo valora su entorno más cercano la actividad emprendedora afecta directa e indirectamente a la intención de crear un nuevo negocio. El impacto indirecto de esta percepción es a través de la AE. Es decir, las mujeres 
perciben mayor atractivo en crear su propio negocio si consideran que su entorno cercano valora favorablemente la actividad emprendedora. Esto puede deberse a una autoestima más baja que les haga buscar apoyos más allá de la percepción de sus propias capacidades. De hecho, la NS (valoración del emprendimiento de la propia encuestada por personas cercanas) influye significativamente tanto indirectamente como directamente en la IE. En este punto se han encontrado diferencias con el estudio de Sahinidis et al. (2012) que señalaban que las variables del entorno estaban relacionadas tanto con la AE como con la CCP. Sería interesante seguir indagando si esta diferencia está relacionada con la orientación profesional de los estudiantes investigados o es debida a aspectos socio-culturales.

Se constata que el emprendimiento en el sector de la comunicación sigue siendo una actividad masculina, en una profesión masculinizada (Djerf-Pierre, 2007), donde los hombres necesitan una menor aprobación por parte del entorno, puesto que se asume que ellos pueden y deben emprender, sin embargo, en el caso de las mujeres es preciso reforzar el atractivo del emprendimiento con el apoyo de su entorno más cercano.

Son necesarios más estudios en esta línea orientados a identificar capacidades y competencias que influyan en el comportamiento emprendedor de las mujeres. Es probable que variables como la confianza y la autoestima en relación al emprendimiento estén limitando la capacidad emprendedora de las mujeres que busquen la aprobación del entorno para desarrollar un comportamiento emprendedor. Los formadores tienen que tratar de transmitir el atractivo del emprendimiento a las mujeres emprendedoras.

\section{Implicaciones}

Parece, como apuntan la mayoría de las investigaciones, que la solución a largo plazo para reducir las diferencias de género pasan por modificar el sistema educativo (Sahinidis et al., 2012). Investigaciones como la presente ayudan a identificar los antecedentes sobre los que actuar y que hay que desarrollar en los programas formativos de los futuros comunicadores. Desde el punto de vista metodológico este estudio revela la utilidad y validez del modelo testado. $\mathrm{Al}$ mismo tiempo, se considera necesario realizar estudios cualitativos que permitan incorporar nuevos indicadores que midan los constructos que, como NS y ES, tienen pocos. Del mismo modo, hay que profundizar en la diferencia de género estudiando la inclusión de variables como la existencia de valores de referencia, la situación laboral de las madres o el apoyo institucional. Por último, se anima a los investigadores a realizar estudios centrados en poblaciones profesionales más concretas que ayuden a comprender el fenómeno de la intención 
emprendedora en otras áreas en cuyo programa formativo no se incluyan contenidos relacionados con el mundo empresarial.

Siguiendo las propuestas de BarNir, Watson y Hutchins (2011) es necesario introducir en los procesos de enseñanza aprendizaje de los periodistas dinámicas en las que se presenten casos de éxitos de mujeres emprendedoras en la comunicación que demuestren que iniciarse en la aventura empresarial no tiene que ser una opción de carrera profesional exclusivamente para los hombres (Brito, Cruz \& Hernández, 2014)

\section{Limitaciones del estudio}

Este estudio tiene dos limitaciones. Por una parte el hecho de que se mide la intención emprendedora de forma estática. Sería muy enriquecedor poder hacer un seguimiento de la población objeto de estudio y conocer realmente el emprendimiento a lo largo de su carrera profesional. Es decir, el paso de la intención a la acción. Por otra parte, el hecho de trabajar con estudiantes de periodismo, y aunque la teoría del comportamiento planeado es bastante sólida, no permite generalizar los resultados a los profesionales del sector. Los datos deben ser interpretados como un experimento, algo que explica en un contexto concreto el comportamiento emprendedor. En cualquier caso la investigación es relevante por la contribución que supone para estudios metateóricos sobre el tema y su integración en las conclusiones de los estudios previos y la introducción de las ecuaciones estructurales en los estudios sobre periodismo.

\section{Referencias}

Ajzen, I. (1991). The theory of planned behavior. Organizational behavior and buman decision processes, 50(2), 179-211. https://doi.org/10.1016/0749-5978(91)90020-T

Ajzen, I. (2005). Attitudes, personality, and behavior. Reino Unido: McGraw-Hill Education.

Alonso-Galicia, P.E. (2012). La configuración de la intención emprendedora entre académicos responsables de proyectos de investigación en España. Un enfoque de género. Tesis de doctorado. Granada, Departamento de Economía financiera y Contabilidad, Universidad de Granada.

Arias, A.V., Restrepo, I.M., \& Restrepo, A.M. (2016). Intención emprendedora en estudiantes universitarios: Un estudio bibliométrico. Intangible Capital, 12(4), 881-922. https://doi.org/10.3926/ic.730 
Armitage, C.J., \& Conner, M. (2001). Efficacy of the theory of planned behaviour: A meta-analytic review. British journal of social psychology, 40(4), 471-499. https://doi.org/10.1348/014466601164939

BarNir, A., Watson, W.E., \& Hutchins, H.M. (2011). Mediation and moderated mediation in the relationship among role models, self-efficacy, entrepreneurial career intention, and gender. Journal of Applied Social Psychology, 41(2), 270-297. https://doi.org/10.1111/j.1559-1816.2010.00713.x

Brito, M.D.P.M., Cruz, A.M.B., \& Hernández, A.I.L. (2014). Un paso más en la investigación de la intención emprendedora del estudiante universitario: GUESSS. Revista de Estudios Empresariales, Segunda Época(2), 63-80.

Carmines, E.G., \& Zeller, R.A. (1979). Reliability and validity assessment. N. 07-017, Sage University Paper Series on Quantitative Applications in the Social Sciences. Beverly Hills, CA: Sage. https://doi.org/10.4135/9781412985642

Caro-González, F.J., García-Gordillo, M.D.M., Rodríguez-Rad, C.J., \& Jimenez-Marín, G. (2007). Techo de cristal en las empresas periodísticas: Percepción de las habilidades y capacidades de la mujer en las tareas de dirección. Ámbitos, (16), 395-407.

Carsrud, A., \& Brännback, M. (2011). Entrepreneurial motivations: What do we still need to know?. Journal of Small Business Management, 49(1), 9-26. https://doi.org/10.1111/j.1540-627X.2010.00312.x

Chin, W.W. (1998). The partial least squares approach to structural equation modeling. Modern methods for business research, 295(2), 295-336.

Crant, J.M. (1996). The proactive personality scale as a predictor of entrepreneurial intentions. Journal of small business management, 34(3), 42.

De Pillis, E., \& Reardon, K.K. (2007). The influence of personality traits and persuasive messages on entrepreneurial intention: A cross-cultural comparison. Career Development International, 12(4), 382-396. https://doi.org/10.1108/13620430710756762

Delmar, F., \& Davidsson, P. (2000). Where do they come from? Prevalence and characteristics of nascent entrepreneurs. Entrepreneurship \& Regional Development, 12(1), 1-23. https://doi.org/10.1080/089856200283063

DeMartino, R., \& Barbato, R. (2015). An analysis of the motivational factors of intending entrepreneurs. Journal of Small Business Strategy, 13(2), 26-36. 
Diamantopoulos, A., \& Winklhofer, H.M. (2001). Index construction with formative indicators: An alternative to scale development. Journal of Marketing Research, 38, 269-277. https://doi.org/10.1509/jmkr.38.2.269.18845

Díaz-García, M.C., \& Jiménez-Moreno, J. (2010). Entrepreneurial intention: The role of gender. International Entrepreneurship and Management Journal, 6(3), 261-283. https://doi.org/10.1007/s11365-008$0103-2$

Dimov, D. (2007). Beyond the single-person, single-insight attribution in understanding entrepreneurial opportunities. Entrepreneurship Theory and Practice, 31(5), 713-731. https://doi.org/10.1111/j.15406520.2007.00196.x

Djerf-Pierre, M. (2007). The Gender of Journalism. The Structure and Logic of the Field in the Twentieth Century. Nordicom Review, 28, 81-104

Dyer JR, W.G. (1994). Toward a theory of entrepreneurial careers. Entrepreneurship: Theory and Practice, 19(2), 7-22.

Elfving, J. (2008). Contextualizing Entrepreneurial Intentions: A Multiple Case Study on Entrepreneurial Cognitions and Perceptions. Turku, Finland: ÅboAkademiförlag.

Engle, R.L., Dimitriadi, N., Gavidia, J.V., Schlaegel, C., Delanoe, S., Alvarado, I. et al. (2010). Entrepreneurial intent: A twelve-country evaluation of Ajzen's model of planned behavior. International Journal of Entrepreneurial Behaviour \& Research, 16(1), 35-57. https://doi.org/10.1108/13552551011020063

Farrington, S.M., Venter, D.J.L., \& Louw, M.J. (2012). Entrepreneurial intentions: Demographic perspectives of South African business students. South African Journal of Business Management, 43(3), 41-49.

Fayolle, A., \& Gailly, B. (2004, July). Using the theory of planned behaviour to assess entrepreneurship teaching programs: A first experimentation. In Intent 2004 conference. Available online at: http://www.researchgate.net/publication/228752441

Fini, R., Grimaldi, R., Marzocchi, G.L., \& Sobrero, M. (2012). The determinants of corporate entrepreneurial intention within small and newly established firms. Entrepreneurship Theory and Practice, 36(2), 387-414. https://doi.org/10.1111/j.1540-6520.2010.00411.x

Fornell, C., \& Larcker, D.F. (1981). Evaluating structural equation models with unobservable variables and measurement error. Journal of marketing research, 18(1), 39-50. https://doi.org/10.2307/3151312 
Gallurt Plá, P. (2010). Creación de «spin-offs» en las universidades españolas: Un modelo de intenciones. Doctoral dissertation, tesis doctoral. Sevilla, Departamento de Dirección de Empresas, Universidad Pablo de Olavide.

Gatewood, E.J., Shaver, K.G., Powers, J.B., \& Gartner, W.B. (2002). Entrepreneurial expectancy, task effort, and performance. Entrepreneurship theory and practice, 27(2), 187-206. https://doi.org/10.1111/1540-8520.00006

George, D., \& Mallery, M. (2003). Using SPSS for Windows step by step: a simple guide and reference. Boston, MA: Allyn \& Bacon.

Gird, A., \& Bagraim, J.J. (2008). The theory of planned behaviour as predictor of entrepreneurial intent amongst final-year university students. South African Journal of Psychology, 38(4), 711-724. https://doi.org/10.1177/008124630803800410

González-Serrano, M.H., Valantine, I., Campos, C.P., Berenguer, S.A., Moreno, F.C., \& Hervás, J.C. (2016). La influencia del género y de la formación académica en la intención de emprender de los estudiantes de ciencias de la actividad física y el deporte. Intangible Capital, 12(3), 759-788. https://doi.org/10.3926/ic.783

Goyanes, M. (2015). Factors Affecting the Entrepreneurial Intention of Students Pursuing Journalism and Media Studies: Evidence from Spain. International Journal on Media Management, 17(2), 109-126. https://doi.org/10.1080/14241277.2015.1055748

Guerrero, M., Lavín, J., \& Álvarez, M. (2009). The role of education on start-up intentions: A structural equation model of Mexican university students. In 35th annual conference proceedings of the Association for Small Business and Entrepreneurship.

Guerrero, M., Rialp, J., \& Urbano, D. (2008). The impact of desirability and feasibility on entrepreneurial intentions: A structural equation model. International Entrepreneurship and Management Journal, 4(1), 35-50. https://doi.org/10.1007/s11365-006-0032-x

Harrison, G.W., \& List, J.A. (2004). Field experiments. Journal of Economic literature, 42(4), 1009-1055. https://doi.org/10.1257/0022051043004577

Henseler, J., Ringle, C.M., \& Sarstedt, M. (2015). A new criterion for assessing discriminant validity in variance-based structural equation modeling. Journal of the Academy of Marketing Science, 43(1), 115-135. https://doi.org/10.1007/s11747-014-0403-8

Jaén, I. (2010). Una revisión teórica de los valores en el estudio de la intención emprendedora. Trabajo de investigación. Sevilla: Universidad de Sevilla. 
Jarvis, J. (2015). El fin de los medios de comunicación de masas. ¿Cómo serán las noticias del futuro?. Barcelona: Ediciones Gestión 2000.

Kickul, J., Gundry, L.K., Barbosa, S.D., \& Whitcanack, L. (2009). Intuition versus analysis?. Testing differential models of cognitive style on entrepreneurial self-efficacy and the new venture creation process. Entrepreneurship Theory and Practice, 33(2), 439-453. https://doi.org/10.1111/j.15406520.2009.00298.x

Kickul, J., Krueger, N., \& Maxfield, S. (2005). Introduction: Special Issue on "Measurement Issues in Entrepreneurship Studies”. New England Journal of Entrepreneurship, 8(2), 2.

Kline, R.B. (2011). Principles and practice of structural equation modeling. New York: Guilford Press.

Kobeissi, N. (2010). Gender factors and female entrepreneurship: International evidence and policy implications. Journal of International Entrepreneurship, 8(1), 1-35. https://doi.org/10.1007/s10843-010-0045-y

Kolvereid, L., \& Isaksen, E. (2006). New business start-up and subsequent entry into self-employment. Journal of Business Venturing, 21(6), 866-885. https://doi.org/10.1016/j.jbusvent.2005.06.008

Krueger, N.F., \& Carsrud, A.L. (1993). Entrepreneurial intentions: Applying the theory of planned behaviour. Entrepreneurship \& Regional Development, 5(4), 315-330. https://doi.org/10.1080/08985629300000020

Krueger, N.F., Reilly, M.D., \& Carsrud, A.L. (2000). Competing models of entrepreneurial intentions. Journal of business venturing, 15(5), 411-432. https://doi.org/10.1016/S0883-9026(98)00033-0

Lee, S.H., \& Wong, P.K. (2004). An exploratory study of technopreneurial intentions: A career anchor perspective. Journal of Business Venturing, 19(1), 7-28. https://doi.org/10.1016/S0883-9026(02)00112-X

Leroy, H., Maes, J., Sels, L., Debrulle, J., \& Meuleman, M. (2009). Gender effects on entrepreneurial intentions: A Tab Multi Group Analysis at factor and indicator level. Paper presented at the Academy of Management Annual Meeting.

Liñán, F., \& Chen, Y.W. (2009). Development and Cross-Cultural application of a specific instrument to measure entrepreneurial intentions. Entrepreneurship theory and practice, 33(3), 593-617. https://doi.org/10.1111/j.1540-6520.2009.00318.x

Liñán, F., \& Santos, F.J. (2007). Does social capital affect entrepreneurial intentions?. International Advances in Economic Research, 13(4), 443-453. Available online at: http://hdl.handle.net/10.1007/s11294007-9109-8 https://doi.org/10.1007/s11294-007-9109-8 
Liñán, F., Rodriguez-Cohard, J.C., \& Rueda-Cantuche, J.M. (2005). Factors affecting entrepreneurial intention levels. In 45th Congress of the European Regional Science Association, Amsterdam (pp. 23-27). Available online at: http://hdl.handle.net/10419/117622

Liñán, F., Rodríguez-Cohard, J.C., \& Rueda-Cantuche, J.M. (2011). Factors affecting entrepreneurial intention levels: A role for education. International entrepreneurship and management Journal, 7(2), 195-218. https://doi.org/10.1007/s11365-010-0154-z

Lüthje, C., \& Franke, N. (2003). The 'making' of an entrepreneur: Testing a model of entrepreneurial intent among engineering students at MIT. R\&D Management, 33(2), 135-147. https://doi.org/10.1111/1467-9310.00288

Martínez, J., Mira, I., \& Gómez, J. (2010). Nascent Entrepreneurship and perceptual variables from a gender overview. Differences in different economic climates. In V Workshop de Investigación basada en GEM, Cádiz.

Palacios, L. (2015). Informe anual de la profesión periodística, 2015. Madrid, APM.

Peña, I., Guerrero, M., González-Pernía, J.L., Turró, A., Urbano, D., de Pablo, I. et al. (2016). Global Entrepreneurship Monitor. Informe GEM España 2015(Vol. 22). Ed. Universidad de Cantabria.

Prodan, I., \& Drnovsek, M. (2010). Conceptualizing academic-entrepreneurial intentions: An empirical test. Technovation, 30(5), 332-347. https://doi.org/10.1016/j.technovation.2010.02.002

Pruett, M., Shinnar, R., Toney, B., Llopis, F., \& Fox, J. (2009). Explaining entrepreneurial intentions of university students: A cross-cultural study. International Journal of Entrepreneurial Behavior \& Research, 15(6), 571-594. https://doi.org/10.1108/13552550910995443

Rigdon, E.E. (2016). Choosing PLS pathmodeling as analytical method in European management research: A realist perspective. European Management Journal, 34(6), 598.

https://doi.org/10.1016/j.emj.2016.05.006

Ringle, C.M., Wende, S., \& Will, A. (2005). SmartPLS 2.0 (M3) beta. Hamburg. Available online at: http://www.smartpls.de/

Sagie, A., \& Elizur, D. (1999). Achievement motive and entrepreneurial orientation: A structural analysis. Journal of Organizational Behavior, 20(3), 375-387. Available online at:

http://www.jstor.org/stable/3100296 $\quad$ https://doi.org/10.1002/(SICI)1099-1379(199905)20:3<375::AIDJOB884>3.0.CO;2-Y 
Sahinidis, A.G., Giovanis, A.N., \& Sdrolias, L. (2012). The role of gender on entrepreneurial intention among students: An empirical test of the theory of planned behaviour in a Greek university. International Journal on Integrated Information Management, 1(1), 61-79. https://doi.org/10.15556/IJIIM.01.02.005

Sánchez, J.C., Lanero, A., \& Yurrebaso, A. (2005). Variables determinantes de la intención emprendedora en el contexto universitario (Determinant Variables of theEntrepreneurial Intention in the University Context). Revista de Psicología Social Aplicada, 15(1), 37-60.

Shay, J., \& Terjensen, S. (2005). Entrepreneurial aspirations and intentions of business students: A gendered perspective. In Paper presentado en the Babson Entrepreneurship Conference, Boston, MA.

Shook, C.L., \& Bratianu, C. (2010). Entrepreneurial intent in a transitional economy: An application of the theory of planned behavior to Romanian students. International Entrepreneurship and Management Journal, 6(3), 231-247. https://doi.org/10.1007/s11365-008-0091-2

Souitaris, V., Zerbinati, S., \& Al-Laham, A. (2007). Do entrepreneurship programmes raise entrepreneurial intention of science and engineering students? The effect of learning, inspiration and resources. Journal of Business venturing, 22(4), 566-591. https://doi.org/10.1016/j.jbusvent.2006.05.002

Tenenhaus, M., Vinzi, V.E., Chatelin, Y.M., \& Lauro, C. (2005). PLS pathmodeling. Computational statistics \& data analysis, 48(1), 159-205. https://doi.org/10.1016/j.csda.2004.03.005

Ventura, R., \& Quero, M.J. (2013). Using Facebook in university teaching: A practical case study. Procedia-Social and Behavioral Sciences, 83, 1032-1038. https://doi.org/10.1016/j.sbspro.2013.06.192

White, K.M., Smith, J.R., Terry, D.J., Greenslade, J.H., \& McKimmie, B.M. (2009). Social influence in the theory of planned behaviour: The role of descriptive, injunctive, and in-group norms. British Journal of Social Psychology, 48(1), 135-158. https://doi.org/10.1348/014466608X295207

Wilson, F., Kickul, J., \& Marlino, D. (2007). Gender, entrepreneurial Self-Efficacy, and entrepreneurial careerintentions: Implications for entrepreneurship Education 1. Entrepreneurship theory and practice, 31(3), 387-406. https://doi.org/10.1111/j.1540-6520.2007.00179.x

Wurthmann, K. (2014). Business students' attitudes toward innovation and intentions to start their own businesses. International Entrepreneurship and Management Journal, 10(4), 691-711. https://doi.org/10.1007/s11365-013-0249-4

Zahra, S.A., Gedajlovic, E., Neubaum, D.O., \& Shulman, J.M. (2009). A typology of social entrepreneurs: Motives, search processes and ethical challenges. Journal of business venturing, 24(5), 519-532. https://doi.org/10.1016/j.jbusvent.2008.04.007 
Zhao, H., Seibert, S.E., \& Hills, G.E. (2005). The mediating role of self-efficacy in the development of entrepreneurial intentions. Journal of applied psychology, 90(6), 1265. https://doi.org/10.1037/00219010.90.6.1265

Intangible Capital, 2017 (www.intangiblecapital.org)

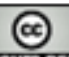

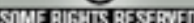

Article's contents are provided on an Attribution-Non Commercial 3.0 Creative commons license. Readers are allowed to copy, distribute and communicate article's contents, provided the author's and Intangible Capital's names are included. It must not be used for commercial purposes. To see the complete license contents, please visit http://creativecommons.org/licenses/by-nc/3.0/. 